\title{
RELACIONES ENTRE FOTOGRAFÍA Y DEMÁS ICONOGRAFÍA DE LA GUERRA DEL PARAGUAY*
}

\author{
Connection between photography and other types of iconography of the \\ Paraguayan War
}

\begin{abstract}
Alberto Del Pino**
\section{Resumen}

Este trabajo intenta establecer algunas conexiones existentes entre fotografía y demás iconografía generada por el conflicto armado, entendidos sus distintos soportes (óleo, acuarela, grabado, litografía, xilografías, etc.). El aporte es eminentemente gráfico y se han compulsado numerosos repositorios públicos así como colecciones privadas en Argentina, Paraguay, Brasil y Uruguay. Se acudió a diversos trabajos relacionados con la iconografía de la guerra, tanto editados como inéditos (libros, artículos, monografías y ponencias). Formulamos una hipótesis sobre el porqué de la ausencia de un adecuado inventario actual de las fotografías, propiciada por la dispersión de las colecciones originales, así como quizás por la escasa investigación que se realiza de las mismas dentro de las instituciones que las custodian. La mayoría de las fotografías carece de datos y eso obsta para su identificación y una adecuada catalogación en los repositorios donde se preservan. Uno de los aspectos más interesantes a destacar, es la confusión de identidad en las fotografías de personajes, lo cual deja evidencia de la carencia de información que existe en la etapa de incorporación del material a su reservorio definitivo.
\end{abstract}

$<$ Fotografía bélica $><$ Iconografía $><$ Guerra del Paraguay $><$ Dispersión regional $>$

\begin{abstract}
This work aims to establish some connections between photography and other types of iconography (such as oil, aquarelle, gravure, lithography, xylography, etc.) built by the armed conflict. This article is entirely illustrated and provides different investigations from diverse public files as well as private collections from Argentina, Paraguay, Brazil, and Uruguay. It gathers various iconography of war related material, both published and unpublished (books, articles, monographs and papers) work. Some hypothesis have been made regarding the current absence of an adequate photography inventory, propitiated by the dispersion of the original collections or the slight investigations that took place in the public files where the materials are. Most of the photographies do not have significant data about them and that limits their proper identification and an adequate classification in the repositories where are preserved. One of the aspects to highlight is the confusion regarding the identity of the characters portrayed in the photography. This illustrates the lack of evidence that exists in the material incorporation stage to its final reservoir.
\end{abstract}

$$
<\text { war photography }><\text { iconography }><\text { Paraguayan War }><\text { regional dispersion }>
$$

\footnotetext{
* En Paraguay prevalece la denominación Guerra Grande, Guerra del 70 o Guerra contra la Triple Alianza. En Argentina, Uruguay y Brasil, casi desde su estallido, se la llamó Guerra del Paraguay. En ámbitos fuera de los países actores ha predominado el de Guerra de la Triple Alianza, que alterna con las anteriores denominaciones dadas al conflicto armado.

** Instituto Histórico y Geográfico del Uruguay (IHGU). delpinomenck@gmail.com
} 


\section{Fotografía y conflicto armado en América: primera mitad del siglo XIX}

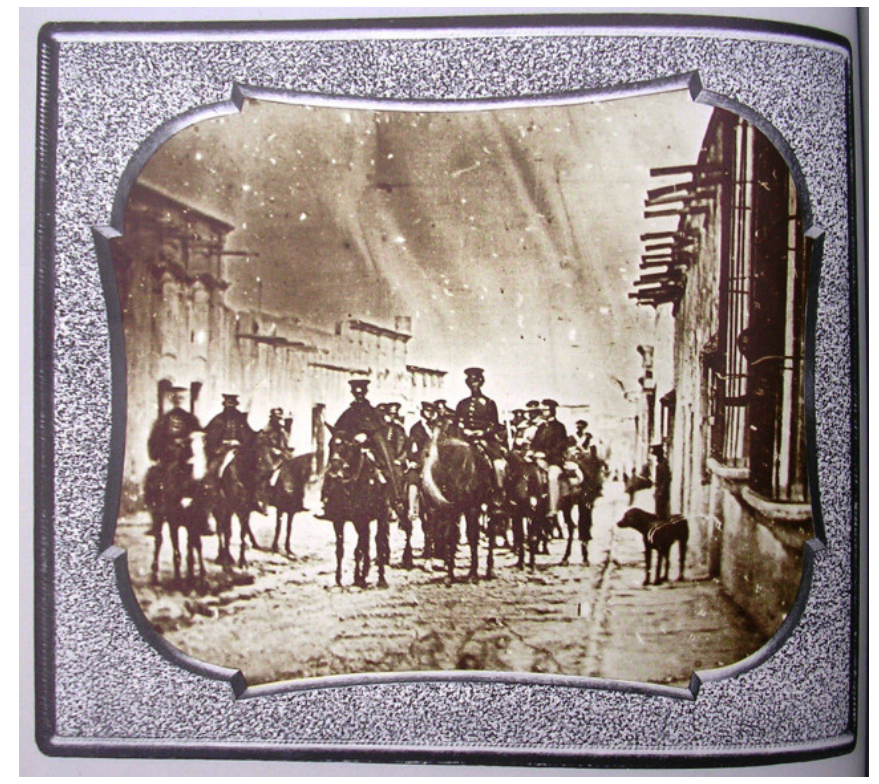

Fig. 1. General John Ellis Wool y su Estado Mayor, en la calle Real de Saltillo en 1847, durante la guerra entre México y Estados Unidos. Este daguerrotipo anónimo tendría el honor de ser considerado la primer imagen de carácter bélico registrada por una cámara. América pues, sería pionera en la saga del reportaje fotográfico de conflictos armados (Yale University Library)

Máquina del tiempo. Así define en una sola frase a la tecnología fotográfica el especialista español Bernardo Riego Amézaga (Riego, 1996: 163), resaltando desde su aparición a pocas décadas de iniciado el Siglo XIX, su enorme poder seductor y evocador para la sociedad contemporánea al hacer posible captar al mundo visible en una imagen registrada a través de una cámara. Temprano se incorporaría el novel adelanto tecnológico para obtener imágenes de contenido bélico, rivalizando con la labor que llevaban adelante desde muchos siglos atrás, artistas que dotados de las más diversas técnicas del arte, representaban episodios de enfrentamientos guerreros. Sobre este papel de la fotografía asociada a la guerra escribe Susan Sontag: "Desde que se inventaron las cámaras en 1839, la fotografía ha acompañado a la muerte. Puesto que la imagen producida con una cámara es, literalmente, el rastro de algo que se presenta ante la lente, las fotografías eran superiores a toda pintura en cuanto evocación de los queridos difuntos y del pasado desaparecido" (Sontag, 2003: 33).

La guerra que mantuvieron entre 1846-1848 Estados Unidos y México generó esas pioneras imágenes de un conflicto armado con un uso moderado de la nueva tecnología, en una serie de daguerrotipos del conflicto donde predomina el retrato individual de los combatientes. A esta, le siguen incipientes reportajes en la rebelión de los cipayos (1857) y en la segunda guerra del Opio en China (1860) anota nuevamente 
Sontag. Sin embargo, el comienzo del uso sistemático de la fotografía cubriendo un conflicto bélico, podemos situarlo desde comienzos de marzo de 1855. Entonces comenzó a realizar su labor de cuatro meses, el fotógrafo Roger Fenton. Enviado especialmente por el gobierno británico, realizó una amplia cobertura fotográfica de la guerra de Crimea (1854-1856), dejando como legado, junto a sus colegas Robertson y Szathmari, y otros fotógrafos menos conocidos, una considerable cantidad de imágenes fotográficas del conflicto.

Impuesta sólidamente la fotografía para cubrir conflictos bélicos, la Guerra de Secesión norteamericana (1861-1865) se constituyó en la conflagración más fotografiada del siglo XIX, donde se destaca especialmente la excepcional labor de Matthew Brady (1823-1896) y su equipo de operadores, quien generó durante la guerra civil alrededor de 8.000 negativos.

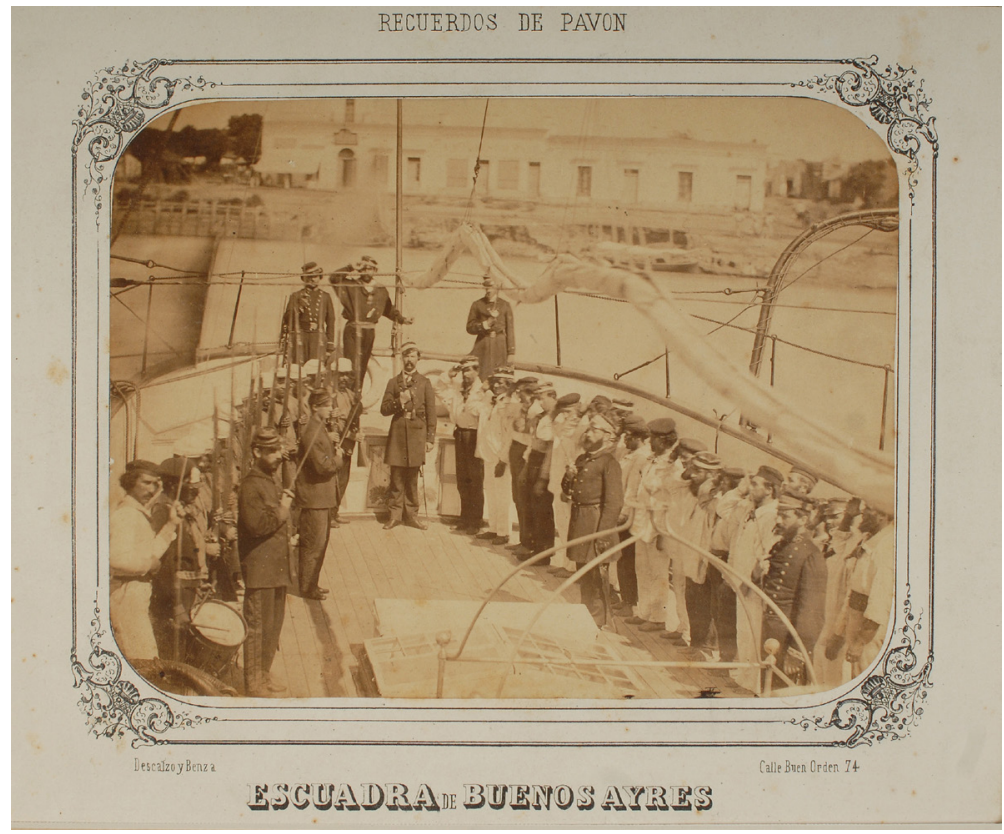

Fig. 2. Descalzo y Benza. Vista de la cubierta del vapor de guerra 25 de Mayo, Álbum de fotografías "Recuerdos de Pavón/Escuadra de Buenos Ayres", albúmina, 19 x 14,5 cm. Museo Mitre, gentileza Lic. Gabriela Mirande Lamédica.

Al promediar el siglo XIX, pululaban los estudios fotográficos en ambas márgenes del Río de la Plata, en distintas capitales del Imperio del Brasil, y en menor medida, en Asunción. ¿Era suficiente y adecuada esta infraestructura para justificar la actividad de reporteros gráficos, cubriendo un conflicto bélico de la envergadura de la Guerra de la Triple Alianza? Durante la campaña de Pavón (1861), los fotógrafos Carlos Descalzo y Paulino Benza, radicados en Buenos Aires, realizaron una serie de fotografías 

de Buenos Ayres", con albúminas sobre cartón, formato "portrait-cabinet".
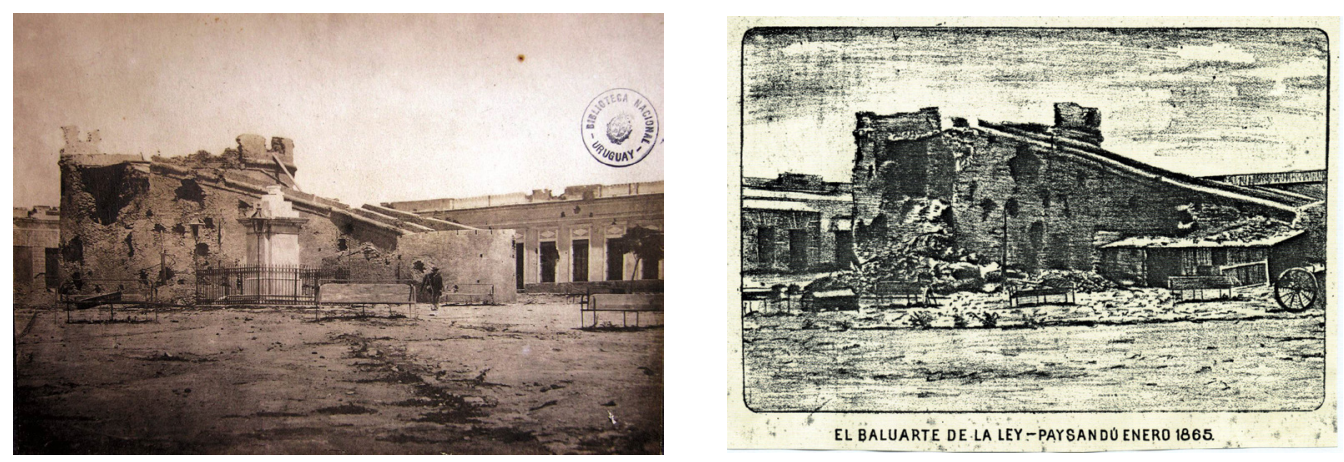

Fig. 3. Anónimo. La jefatura de Policía de Paysandú. Ubicada en la calle 8 de Octubre y Montevideo de la Ciudad de Paysandú, constituía el extremo sudoeste de la línea de trincheras. El edificio había sido recientemente construido, con ventanas enrejadas y altos muros pintados de cal. Fue uno de los bastiones más importantes de la defensa. Albúmina, enero 1865. Inv. ABN 264, Biblioteca Nacional, Materiales Especiales, Montevideo, Uruguay. Figura 4 “La Gefatura - Paysandú enero 1865.”. Litografía anónima publicada en la obra de Rafael Pons y Demetrio Errausquin "La Defensa de Paysandú" (Montevideo, 1887), y basada en la fotografía anterior.

Años más tarde, un anónimo corresponsal de una de las casas fotográficas establecidas en Montevideo, realizó una porción apreciable de tomas en las postrimerías de la guerra civil uruguaya de 1863-1865. Elocuente testimonio de esa cobertura, son las imágenes de las ruinas de Paysandú tras su tenaz y heroica resistencia al embate combinado del caudillo revolucionario general Venancio Flores, los buques de Tamandaré y el ejército de Mena Barreto.

Emilio Lahore (1825-1889), artista francés discípulo de Ingres y de Vernet, que desarrolló una proficua actividad en Buenos Aires (1856), como pintor y daguerrotipista (según el investigador argentino Miguel Ángel Cuarterolo, especializado en historia de la fotografía), el 4 de enero de 1864, realizó vistas fotográficas de la ciudad de Paysandú reducida a escombros luego de los bombardeos brasileños (Cuarterolo, 2000: 150).

Tras estos ensayos preliminares, podemos concluir que la infraestructura tecnológica existente - preponderantemente los estudios fotográficos existentes en el Río de la Plata y en Río de Janeiro - era apta para sustentar una nueva cobertura a través de la cámara fotográfica, del conflicto armado que concitó cinco años de esfuerzo bélico de cuatro estados sudamericanos. El corresponsal de la guerra por antonomasia coronel León de Palleja escribió el 22 de noviembre de 1865 en su diario de campaña desde el campamento de Yaguareté-Corá en Corrientes:

"A las doce del día, el campamento presentaba un golpe de vista magnífico, todos habían tendido sus ropas a secar en ramas, o sobre las carpas; era un bizarro mosaico, donde figuraban 
sin orden ni concierto, todos los colores, sobre un fondo verde esmeralda. Habiendo tanto fotógrafo hoy día en la capital de Montevideo y en Buenos Aires, admira como no se ha animado alguno a seguir los ejércitos aliados y levantar vistas, que de seguro hubieran sido buscadas por su mérito y por el interés que toman en nuestros trabajos y glorias los parientes y amigos de los que componen el ejército aliado; hasta por los extraños hubieran sido procuradas. La gente no se contenta con oir solamente lo que les refieren los periódicos; quiere ver, máxime aquellas escenas principales en que se salva una dificultad o se sustenta un combate. Creo que, aunque tarde, no dejarían de hacer un buen negocio todavía." (De Palleja, 1960: 286-287).

Estas y otras exhortaciones y por supuesto, el afán de lucro, darían motivo finalmente a que la firma Bate y Cía de Montevideo comisionara a su fotógrafo Javier López a Paraguay para una cobertura fotográfica del conflicto que continuaba encarnizado $\mathrm{y}$ sin miras de un pronto desenlace.
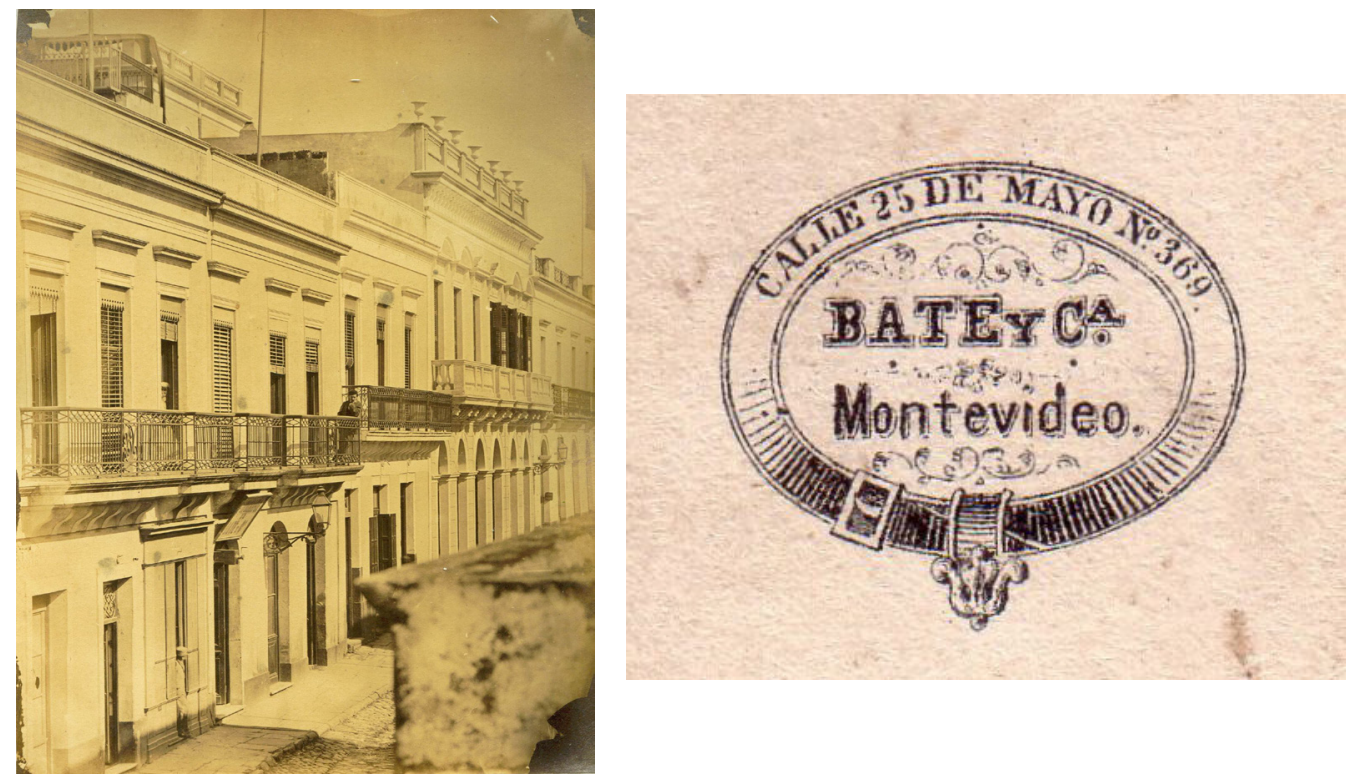

Fig. 5. Local de la firma Bate y Cía en Montevideo, Calle 25 de Mayo No 369, casi Bartolomé Mitre, vereda sud. Se inauguró este estudio el 6 de julio de 1861. En mayo de 1866, la firma fotográfica Bate respondió al desafío y envió a su fotógrafo Javier López al Paraguay. (Museo Histórico Nacional, Montevideo)

En la nota que elevó la mencionada firma con fecha 5 de mayo de 1866 al gobierno de Lorenzo Batlle, procuraba apoyo oficial logístico y financiero, esto último, para solventar los gastos que supondría el emprendimiento. Argumentaba el acicate que suponían las "repetidas insinuaciones de los corresponsales del ejército aliado y a las 
patrióticas indicaciones de varias personas de esta capital" (Del Pino Menck, 1997: 66). Esta decisión y el aval y patrocinio del gobierno uruguayo, hicieron posible la empresa que se gestaba y la realización de una importante colección de imágenes, la más difundida hasta hoy como testimonio fotográfico del conflicto y que llevó como significativo título "La Guerra contra el Paraguay".

De las fotografías que llegaron hasta nuestros días y que conocemos y su relación con la demás iconografía de la guerra intenta hablar este abordaje.

\section{El reinado de la carte de visite}

La tarjeta de visita era el formato usual utilizado en los estudios fotográficos $(8$ X 5 y 10 X $6 \mathrm{~cm}$.), impuesto como uso social en las ciudades de los países en conflicto, ya en pleno auge años antes de que este se iniciara. Patentado el formato "carte de visite" en Paris en 1854 por el francés Adolphe E. Disdéri, se positivaba en copias de contacto en papel fino (albúmina), obtenidas mediante un negativo de vidrio (Del Pino Menck, 2008: 104).

Se cortaban posteriormente y se pegaban sobre un cartón delgado (passpartout), que llevaba al dorso impreso el logo del estudio fotográfico o con sello de goma. Ese espacio del dorso, generalmente era usado para redactar dedicatorias donde figuran además fechas, firmas o datos relevantes que hoy ayudan a identificar estas mismas fotografías.
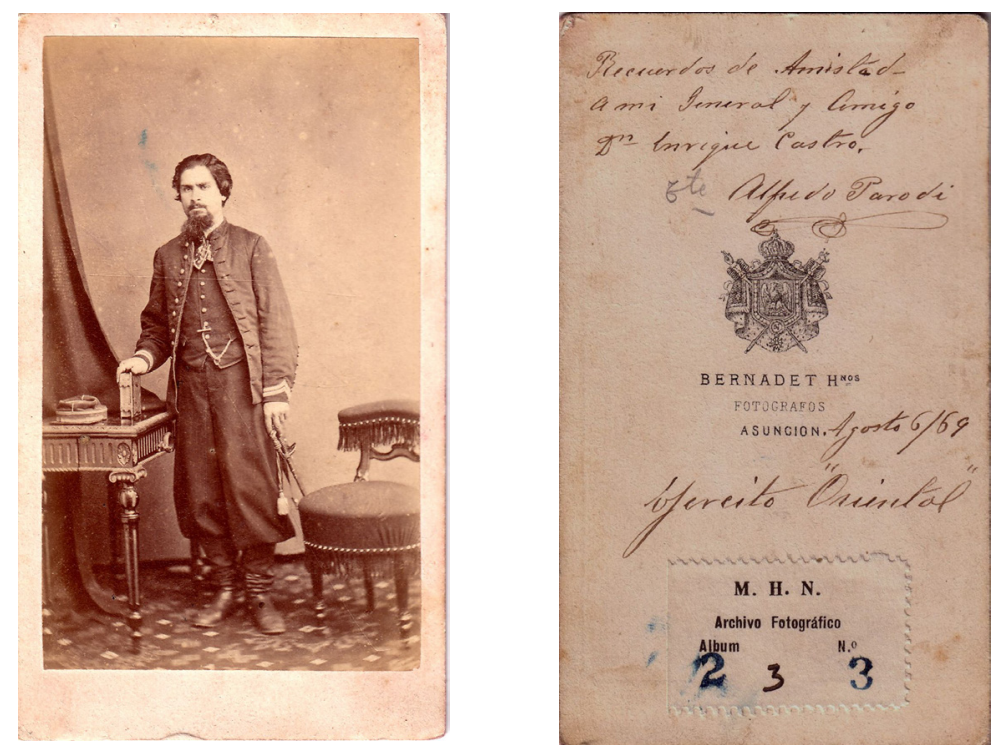

Fig. 6. Bernadet Hermanos, fotógrafos. Teniente Alfredo Parodi del batallón uruguayo "24 de Abril”. Hijo del cónsul de Toscana en Montevideo, este oficial dejó interesante testimonio de su pasaje por la guerra. La foto está fechada durante la ocupación aliada de Asunción y dedicada al comandante en jefe uruguayo General Enrique Castro. Albúmina, formato carte de visite. Álbum $\mathrm{N}^{\circ} 2$, fotografía $\mathrm{N}^{\circ} 3$, Museo Histórico Nacional, Montevideo. 
Convertido en elemento popular y de intercambio entre los oficiales, y en menor medida también entre los soldados y marinos de los cuatro países en pugna, era el obligado recuerdo para familia y amigos al momento de enviar la correspondencia, retratándose aquellos en los estudios asentados en las ciudades o en los que se improvisaron en los campamentos militares. Dice al respecto el Dr. Miguel Ángel De Marco: "Es de imaginar a aquellos muchachos románticos, mostrándose en las noches los retratos de las bellas a la luz mortecina de las velas. Pero ellos no se quedaban atrás en hacerse fotografiar. ¡Es que se veían magníficos con sus dormanes con nudo húngaro y sus quepis requintados, y hasta rodeados de un irresistible halo de misterio con sus anchos capotes y sus bornús!" (De Marco, 1995: 271).

Luego de la caída del gobierno blanco (febrero de 1865) tras la guerra civil de 1863-1865 y la invasión brasileña de 1864, numerosos militares brasileños se retrataron en Montevideo en los distintos estudios fotográficos existentes. Desde 1865, el fotógrafo argentino Saturnino Masoni (1826-1892) - establecido en la calle Rincón 101, Montevideo - registró a muchos de los oficiales uruguayos y brasileños que partían a la campaña contra Paraguay (Del Pino Menck, 2008: 100).
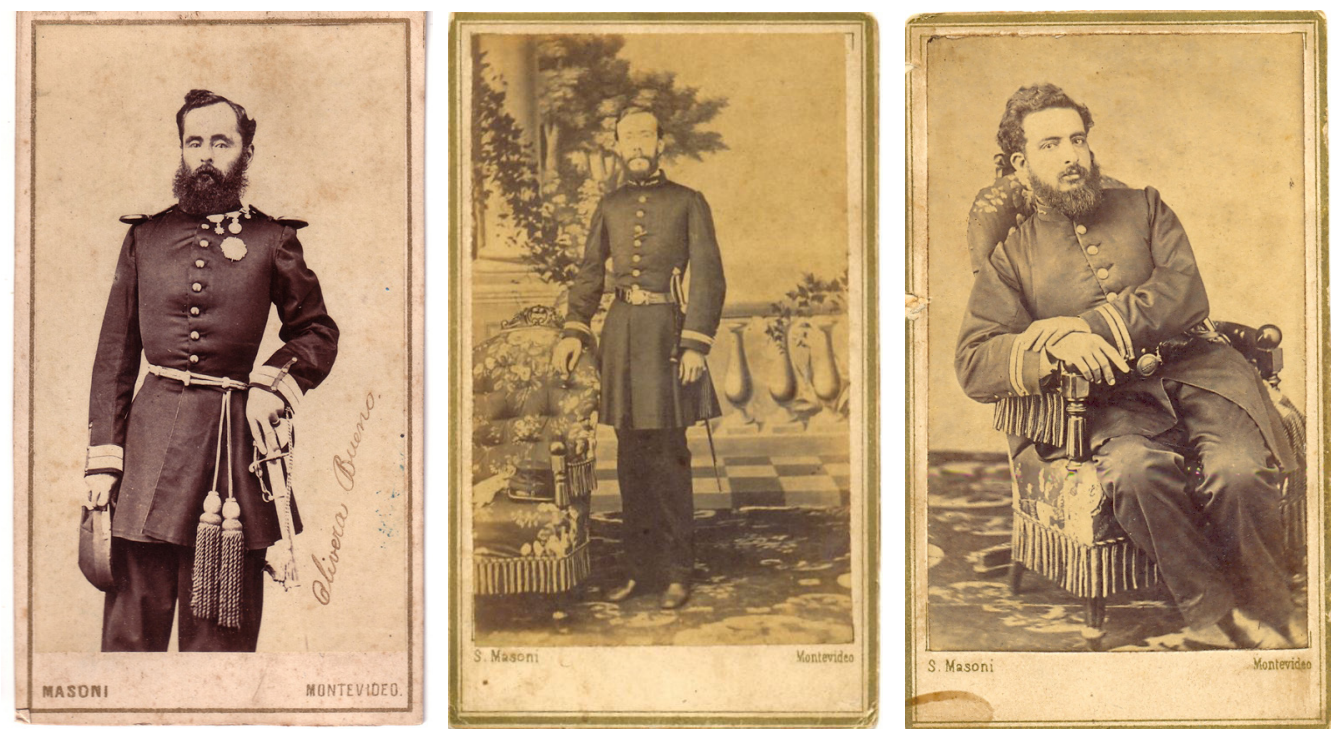

Saturnino Masoni. Tres oficiales brasileños retratados en Montevideo, en el estudio fotográfico Masoni antes de partir a la campaña contra el Paraguay. Fig. 7, 8 y 9 - Teniente Coronel J. Oliveira Bueno, albúmina, formato carte de visite, Museo Histórico Nacional, Montevideo; Oficiales médicos militares brasileños Mell y Bonçallo albúmina, formato carte de visite, Colección Jean Michel Haguenauer, Río de Janeiro.

Veamos lo que dice el diario La Tribuna de Montevideo en su edición correspondiente al 11 de abril de 1865: "Fotografía del Sr. Masoni.- Al visitar la galería de retratos del Sr. Masoni notamos que la mayor parte de los jefes y oficiales brasileros 
se habían hecho retratar allí. Ayer tuvimos ocasión de ir otra vez a esa galería y notamos, no sin sorpresa, que cuarenta y tantos oficiales brasileros habían aumentado la clientela del Sr. Masoni" (Varese, 2013:101).

En nuestras pesquisas, pudimos encontrar asimismo, diseminadas en distintos repositorios públicos y privados paraguayos y uruguayos, diversas fotografías formato carte de visite pertenecientes a variados oficiales paraguayos, posando en un desconocido estudio de Asunción, ya que no aparece al dorso del passpartout de cada una de ellas, indicación alguna de la casa fotográfica donde fueron tomadas.
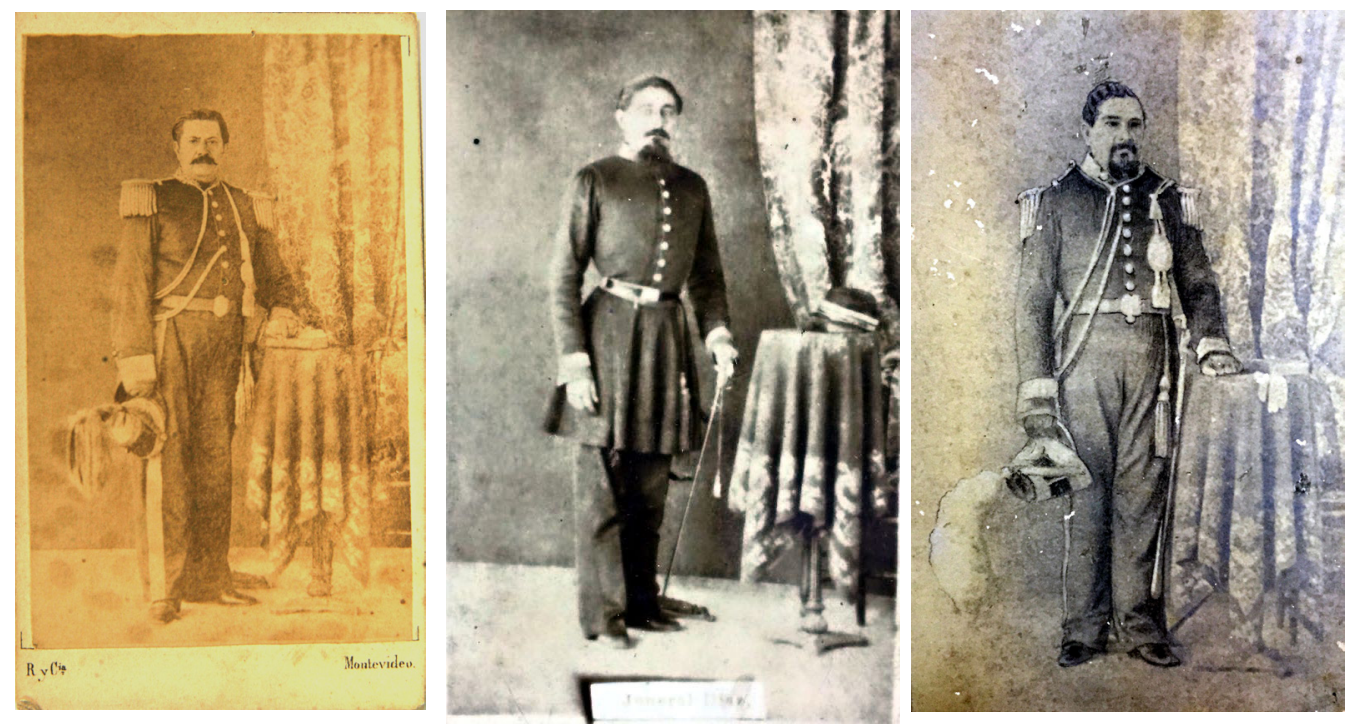

Fig. 10. Renoleau y Cía. Coronel Wenceslao Robles. Se trata de una reproducción del retrato original realizado en un anónimo estudio asunceno. ca. 1864. Albúmina, carte de visite, Museo Histórico Nacional, Montevideo, Uruguay. Fig. 11 Anónimo. Teniente $1^{\circ}$ José E. Díaz, Jefe de Policía de Asunción, ca. 1865. Albúmina, carte de visite, Museo del Ministerio de Defensa Nacional, Asunción, Paraguay. Fig. 12 Anónimo. Teniente Coronel Hermógenes Cabral, instructor en Humaitá. Ca. 1864. Albúmina, carte de visite, Biblioteca Nacional, Asunción, Col. Juan E. O’Leary.

Todas corresponden a ese desconocido estudio fotográfico asunceno, y pertenecen a conocidos actores del bando paraguayo a saber teniente José Díaz - entonces Jefe de Policía de Asunción -, Capitán de Fragata José Ignacio Meza, jefe de la escuadra; Coronel Wenceslao Robles (retratado antes de su ascenso a general); Teniente Coronel Hermógenes Cabral, instructor de infantería en Humaitá; edecán Teniente Coronel José María Aguiar; y Teniente farmacéutico Jorge Federico Masterman.

En el caso del futuro general Wenceslao Robles, identificamos a esta fotografia - la cual formaba parte de otras, sin dato alguno - en su reservorio actual en el Museo Histórico Nacional de Montevideo, sirviéndonos de nuestro conocimiento de la vestimenta castrense, inconfundible en los militares de graduación superior paraguayos de la época y en descripciones que hacía de la misma, la prensa uruguaya contemporánea. 
La carte de visite original procedente del estudio originario asunceno, había sido reproducida para su comercialización conjuntamente con otra del capitán José Díaz que no es la que ilustra esta página, en la capital uruguaya por la firma Renoleau y Cía., la cual giraba con el nombre de "Fotografía Universal" en la calle Ituzaingó No 96 de Montevideo, (Del Pino Menck, 2008: 84-87).

\section{Relaciones entre fotografía y demás iconografía del conflicto}

Muchas de las fotografías, obtenidas durante el conflicto, inspiraron creaciones artísticas ulteriores que se basaron enteramente en ellas. Independientemente de su técnica (grabado, litografía, acuarela, óleo), se creó una segunda generación singular de imágenes en donde se ponían en juego la capacidad para producir arte de cada grabador, litógrafo o acuarelista. La Lic. Cecilia Cavanagh, en una obra escrita en coautoría con el Dr. Miguel Ángel De Marco sobre la obra pictórica del general José Ignacio Garmendia, indica que fue durante el siglo XIX donde la fotografía contribuyó al perfeccionamiento de la pintura de carácter histórico, avalada por la escuela realista francesa que exigía una "precisión extrema que solamente puede lograrse mediante la cámara fotográfica" (De Marco, 2005: 5). Identifica al general Garmendia, veterano de la campaña en el bando argentino, quien sin ser fotógrafo, fue el cronista de guerra que utilizó más la fotografía como fuente referencial de sus obras: "En el Álbum de la Guerra del Paraguay, publicado por Peuser, algunos de sus dibujos ya se reproducen con la leyenda "tomado de fotografía". Garmendia, que había sido capitán del ejército aliado y corresponsal del diario La Tribuna, y estudiado pintura con el español Eustaquio Carrandi, prefirió el realismo fotográfico a los bocetos que tomó en los acontecimientos bélicos, porque así lo demandaba el espíritu de la época.

Pocas fotografías han sido tan utilizadas como inspiración para distintas representaciones como esta que nos ocupa. Pocas, asimismo, registran a oficiales muertos en la Guerra del Paraguay. Entre ellas, en el Complejo Museográfico "Enrique Udaondo" de la Provincia de Buenos Aires, se custodiaban años atrás, algunas raras del Comandante José Pipo Giribone y otros oficiales del batallón argentino Legión Voluntarios caídos en combate.

La magnífica aunque macabra imagen de Javier López, registra la escena de la muerte del coronel León de Palleja (1817-1866), jefe del Batallón "Florida" y de la Brigada de Infantería Oriental, rodeado de sus oficiales y soldados que le rinden honores con el arma a la funerala. Para Ricardo Salles - opinión que compartimos - "talvez a melhor fotografia de toda a guerra":

"Em Muerte del coronel Palleja, certamente uma fotografia colhida imediatamente após os acontecimentos, todos os presentes, conscientes da lente do fotógrafo, estão representando o que deles se espera numa imagem feita para 
durar. Num contraste impactante, o corpo de Palleja, na solidão inescrutável da morte, foge à mise-en-escène. Uma bandeira do Uruguai sobre seus pés integra magistralmente todos os elementos da cena: a pose, a morte, a representação da realidade em um tempo homogêneo e vazio, e a arte do fotógrafo (Salles, 2003: 167).

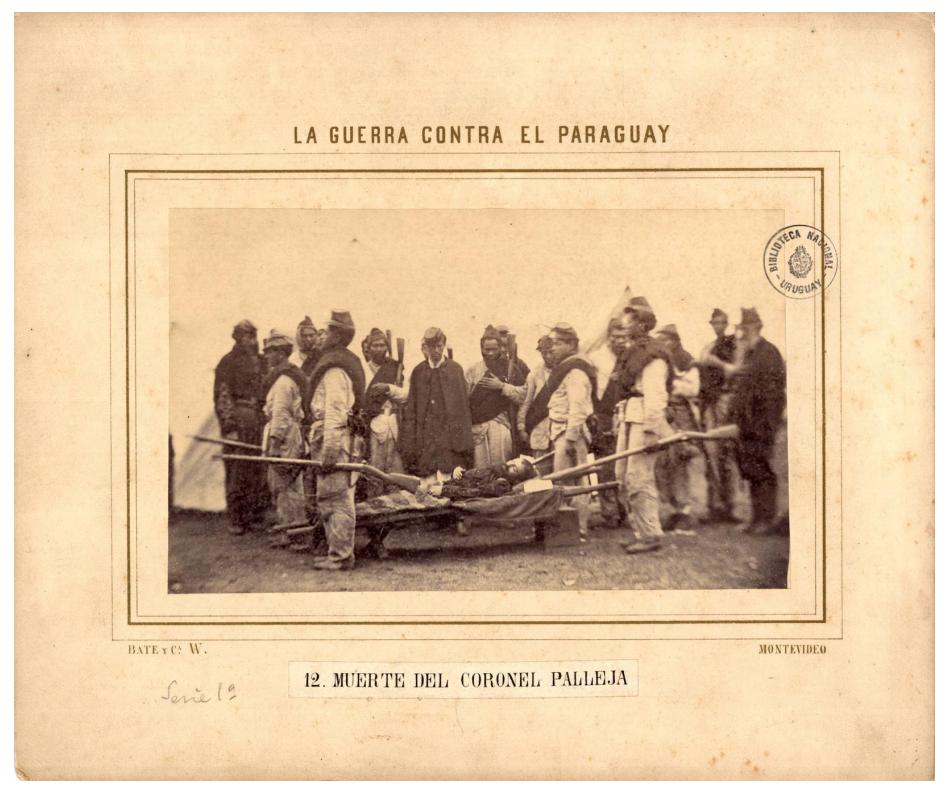

Fig. 13. Javier López, Bate y Cía. Muerte del Coronel Palleja. Esta imagen es la más conocidas de la serie comercializada en Montevideo por el estudio fotográfico Bate y Cía. Fotografía No 12 , Primera serie, primera colección "La Guerra contra el Paraguay", julio de 1866, albúmina $18 \mathrm{~cm}$. X $12 \mathrm{~cm}$., sobre passpartout de cartón con leyendas de 24 X $28 \mathrm{~cm}$. Biblioteca Nacional, Sala de Materiales Especiales, Montevideo, Uruguay.

Es la última de las doce fotografías que conforman la primera serie de "La Guerra contra el Paraguay", fruto del trabajo realizado durante el primer viaje al teatro de operaciones de Javier López. Estas, comenzarían a comercializarse en Montevideo desde el $1^{\circ}$ de agosto de 1866, según anuncio del periódico uruguayo "El Siglo" (Del Pino Menck, 1997: 38-39).

La escena fue realizada en el campamento del ejército uruguayo, ubicado en El Naranjal, próximo a las trincheras de Tuyutí, el mismo 18 de julio de 1866. Según lo que indica el diario montevideano El Siglo - que apoyó en forma entusiasta la labor del fotógrafo López - la toma fue efectuada por orden directa del General Venancio Flores. 


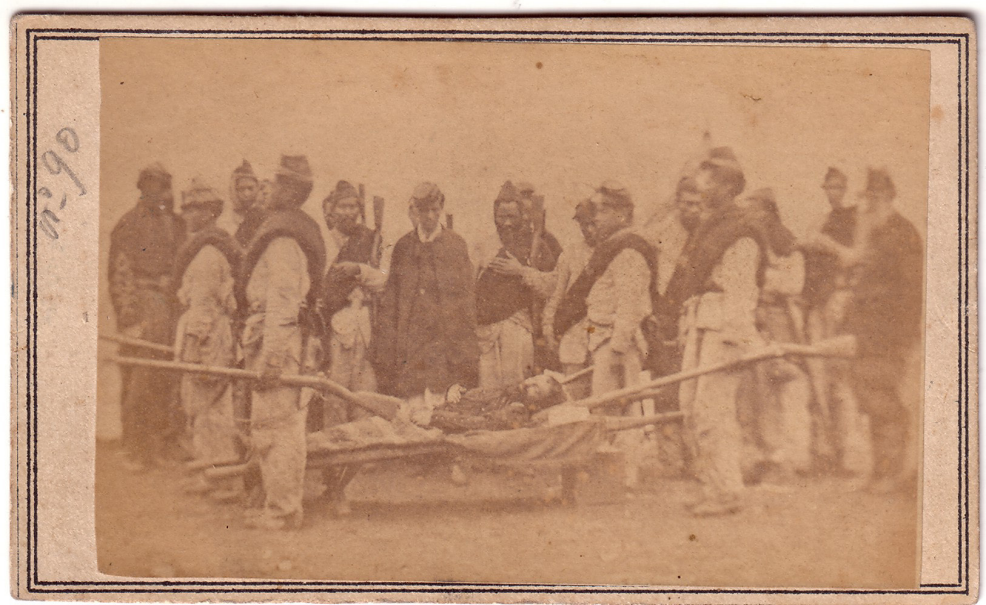

Fig. 14. Javier López, Bate y Cía. Conducción de los restos del coronel Palleja, 18 de julio de 1866, Albúmina, formato carte de visite. Museo Histórico Nacional, Montevideo.

Posteriormente, la firma Bate, también comercializó en Montevideo, esta misma imagen, en formato carte de visite. En enero de 1866, Bate anunciaba a sus clientes, su cierre definitivo, rematando las instalaciones y los negativos en febrero de ese mismo año.

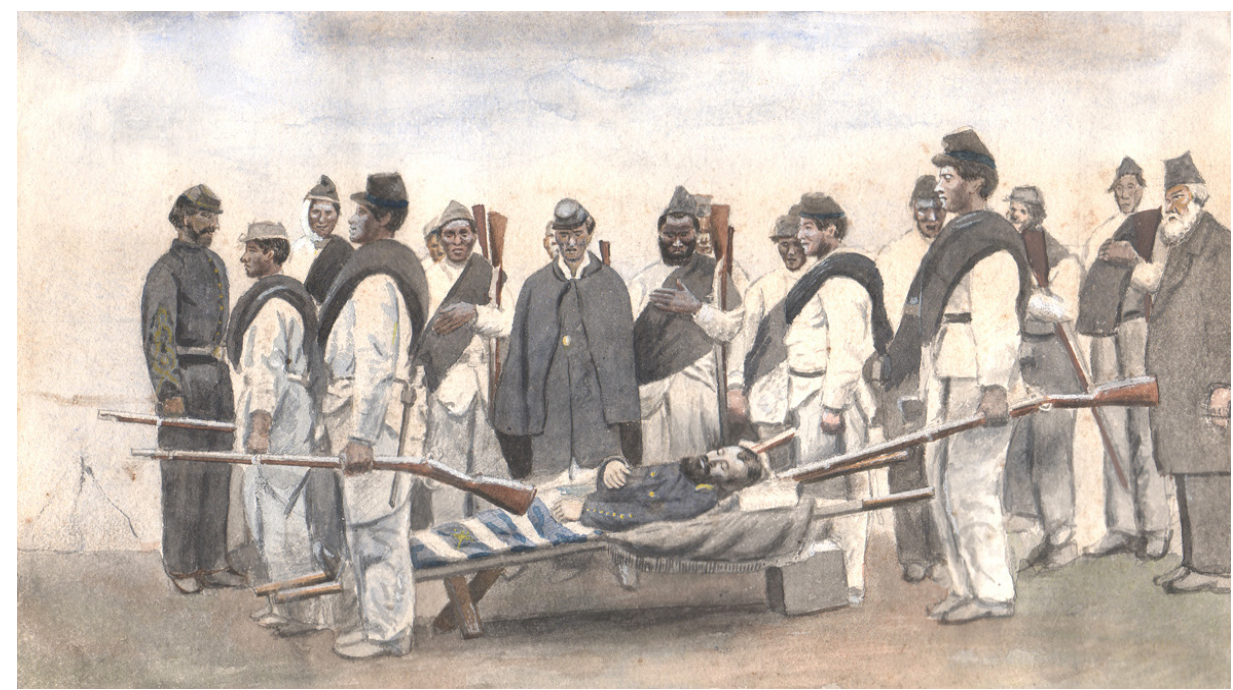

Fig. 15 José Ignacio Garmendia. Fotografía original de Javier López, coloreada por Garmendia. 1866, Acuarela. Museo de la Ciudad de Buenos Aires "Cornelio Saavedra", Buenos Aires, cortesía Lic. Alberto Piñeiro. 


\section{DOSSIER}

Del Pino. Relaciones entre fotografía y demás iconografía de la Guerra del Paraguay

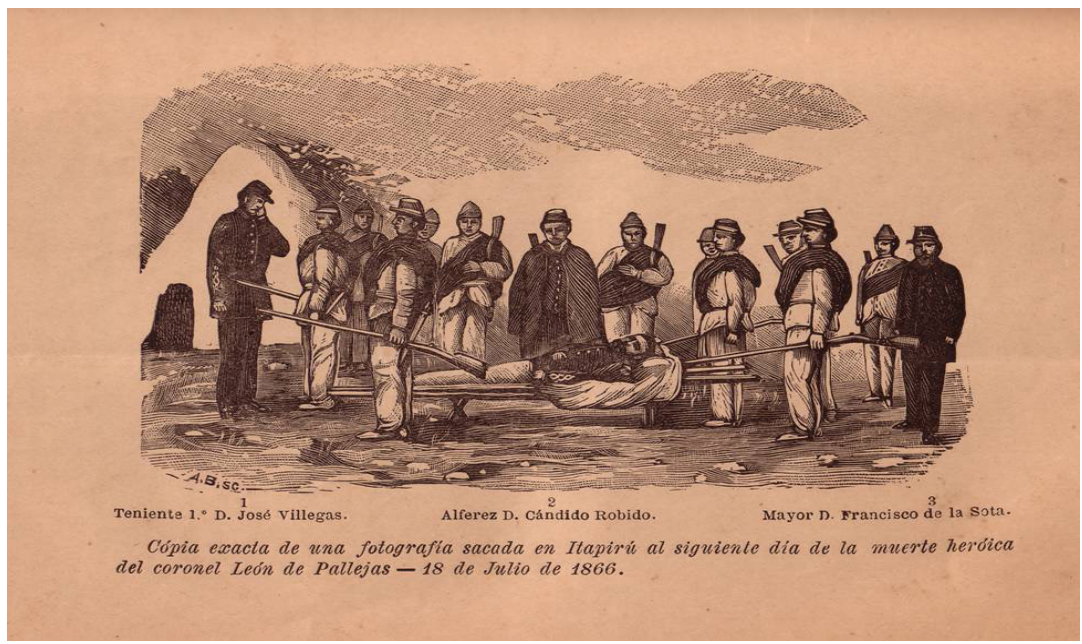

Fig. 16. Anónimo. Erróneamente se afirma que la fotografía en que se basó el artista anónimo, fue tomada en Itapirú. En realidad, solo días después, los restos embalsamados de Palleja viajaban al puerto de Itapirú para embarcarse a Montevideo donde recibiría sepultura. El grabado nos permite conocer la identidad de los tres oficiales que aparecen en la fotografía original que lo inspiró acompañando el cadáver del militar. 18 de julio de 1866. Litografía publicada en el fascículo "Gobierno Provisorio del Brigadier General Venancio Flores - Guerra del Paraguay”, Tomo II, Entrega 3, por Antonio H. Conte, Montevideo, Imprenta Latina, 1898, 32.

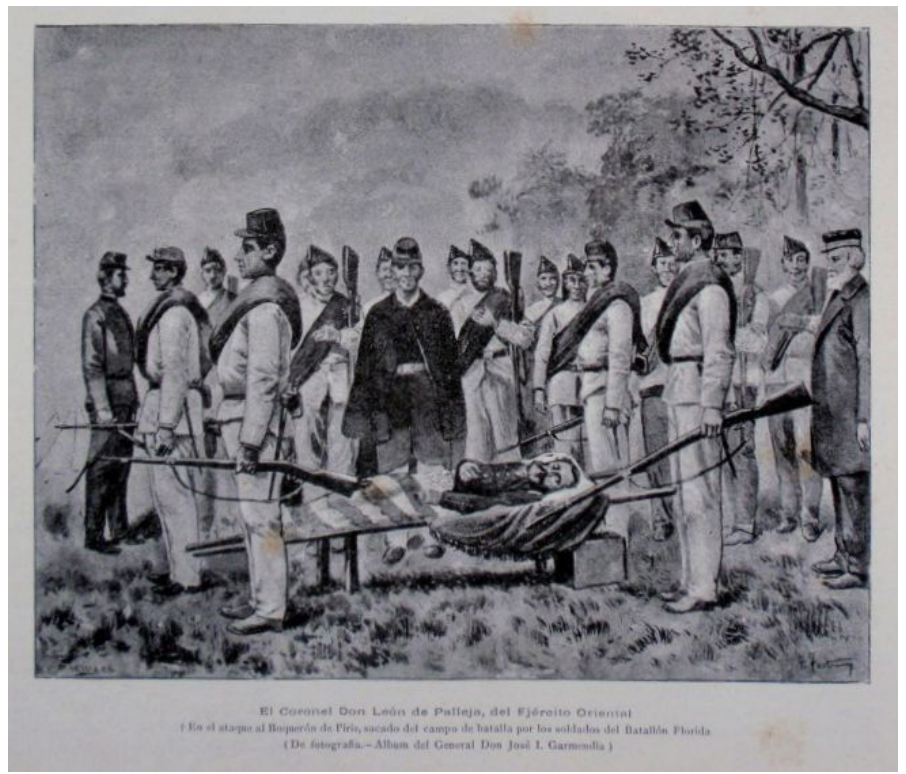

Fig. 17. Francisco Fortuny (1865 Tarragona, España - 1948 Buenos Aires, Argentina). El Coronel Don León de Palleja, del Ejército Oriental. La ilustración está basada en la fotografía de Javier López donde el artista español hizo gala de su destreza con la acuarela, técnica que dominaba recreando numerosas escenas de la guerra, publicadas en los fascículos del Álbum de la Guerra del Paraguay. La publicación coleccionable argentina fue fundada por José Clementino Soto, oficial de artillería y veterano de guerra, cuyo principal ilustrador era el referido Francisco Fortuny.1893. Acuarela. Álbum de la Guerra del Paraguay. Año I, Entrega No 16, 15 de setiembre de 1893. 


\section{Oficiales argentinos retratados por Pedro Bernadet en Corrientes}

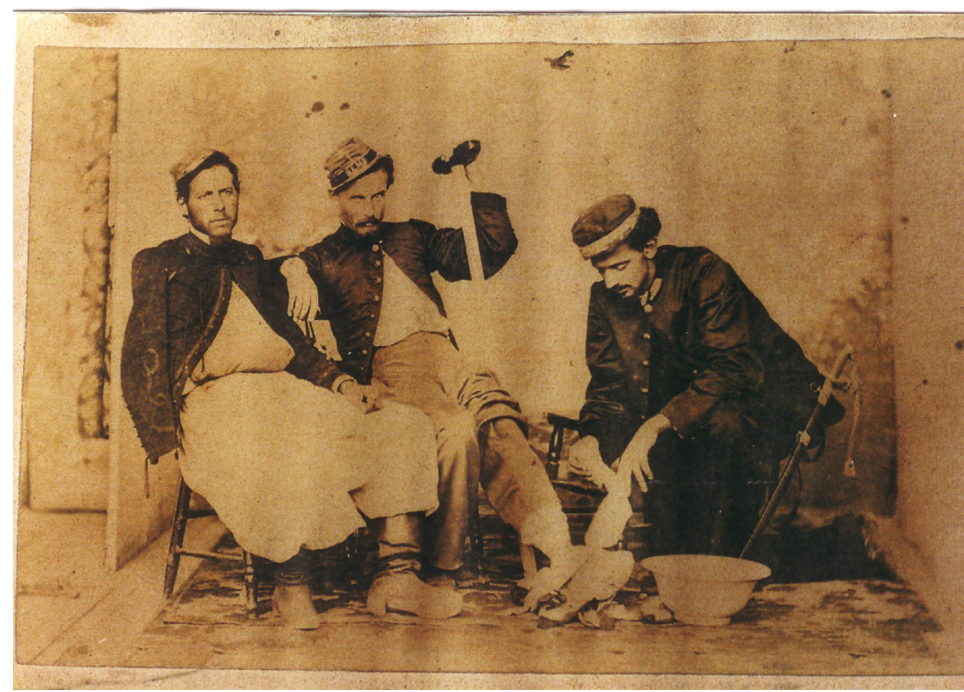

Fig. 18. Pedro Bernadet, Corrientes. En el estudio del fotógrafo francés se retratan de izquierda a derecha, Subteniente Sebastián Casares de la $2^{\mathrm{a}}$ Compañía del Batallón argentino Legión Militar; Subteniente de la $4^{a}$ Compañía, Julio Muzzio del mismo batallón, mientras es atendido este último, por el Practicante del Cuerpo Médico del Ejército Argentino de Operaciones, Carlos Faba. 1866, probablemente, antes del cruce del Paraná por el Ejército Aliado. Albúmina, formato carte de visite. Colección Dr. Diego Mantilla, Corrientes, cortesía Sr. Mario Chaves.

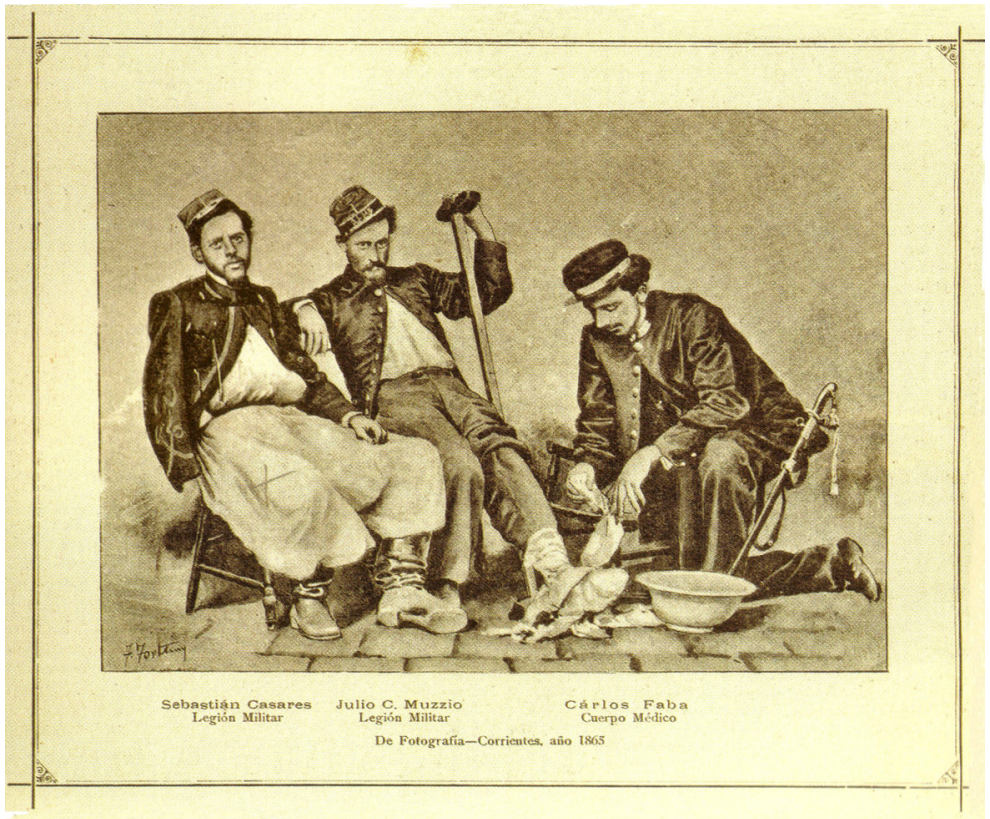

Fig. 19. Francisco Fortuny (1865 Tarragona, España - 1948 Buenos Aires, Argentina). La alfombra del estudio fotográfico correntino del francés Pedro Bernadet, ha sido sustituida por el artista, por un embaldosado de piedra. En abril de 1865 se produjo la invasión paraguaya y Pedro Bernadet comenzó a realizar fotografías de los jefes y oficiales paraguayos de las fuerzas de ocupación. Luego del abandono de la ciudad por los paraguayos, le llegaría el turno a cientos de oficiales aliados que se retrataron en ese mismo estudio. 1894. Acuarela. Álbum de la Guerra del Paraguay. 


\section{DOSSIER}

Del Pino. Relaciones entre fotografía y demás iconografía de la Guerra del Paraguay

\section{Indios del Chaco retratados durante la guerra}

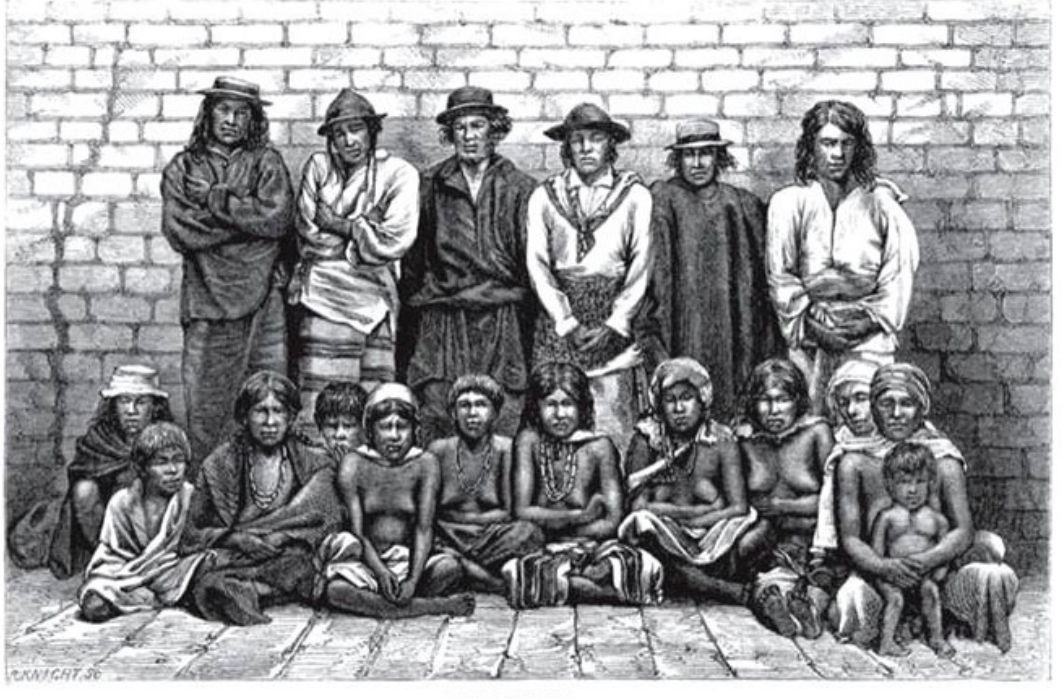

PARAGUAYAR.

Fig. 20. E. Knights S.C., "Paraguayans". La litografía solo lleva el expresivo título de "Paraguayans" y está basado en la fotografía que veremos a continuación. Las dificultades técnicas de la época hicieron posible la reproducción a través de la técnica litográfica de muchas de estas imágenes fotográficas, tanto en libros como en la prensa periódica de la época. 1870. Grabado. Richard Burton "Letters from the Battle-fields of Paraguay", Londres, Tinslby Brothers, 1870.

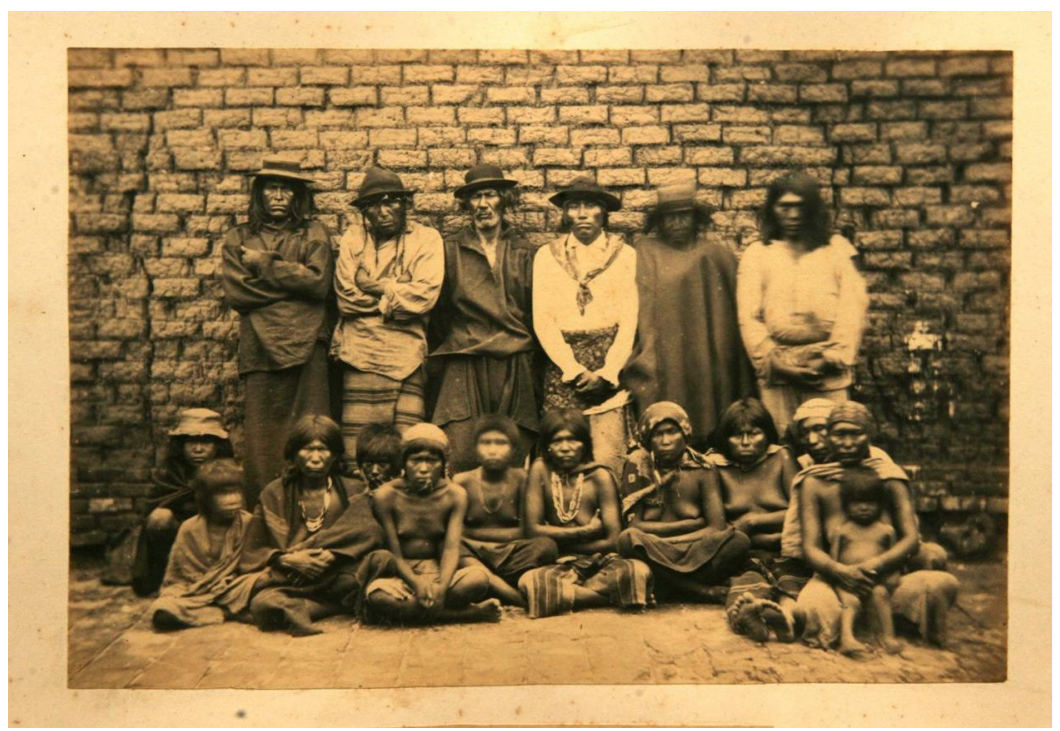

Fig. 21. Anónimo. Indios del Chaco. Esta fotografía también ha sido publicada en el libro de Ricardo

Salles "Guerra do Paraguai: escravidao e cidadania na formaçao do exército", perteneciente al acervo de la Biblioteca Nacional de Río de Janeiro. Se conservan varias fotografías distintas de estos mismos indígenas lo cual nos habla de la dispersión de una serie original ahora dislocada en múltiples repositorios. Ca. 1869. Albúmina, formato portrait cabinet. Museo Histórico Nacional, Montevideo, Uruguay. 


\section{Prisioneros paraguayos retratados por Javier López}

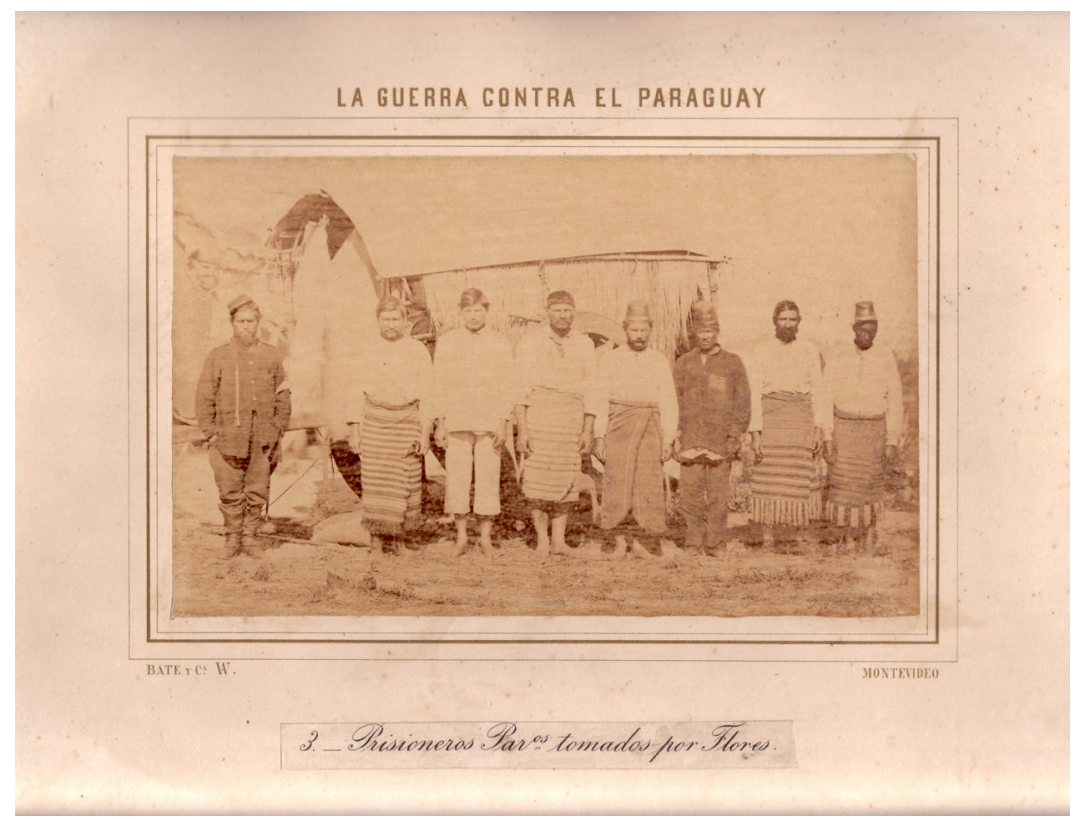

Fig. 22. Javier López. Prisioneros paraguayos tomados por Flores. Fotografía realizada por el equipo dirigido por López en su segundo viaje al Paraguay. 1866. Albúmina sobre cartón, formato portrait cabinet, Fotografía No 3, Segunda colección "La Guerra contra el Paraguay", Museo Histórico Nacional, Montevideo.

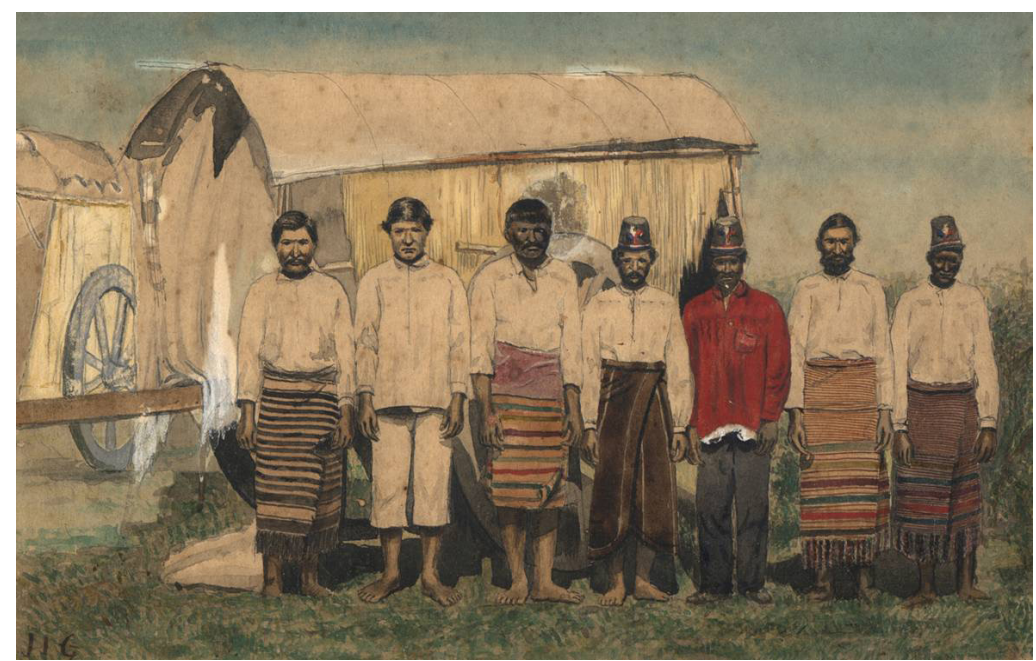

Fig. 23. José Ignacio Garmendia. Pintura ejecutada sobre la propia fotografía de Bate y Cía.

Proporciona el colorido de la vestimenta de los soldados paraguayos como inestimable testimonio. 1866. Acuarela. Museo de la Ciudad de Buenos Aires "Cornelio de Saavedra", gentileza Lic. Alberto Piñeiro 


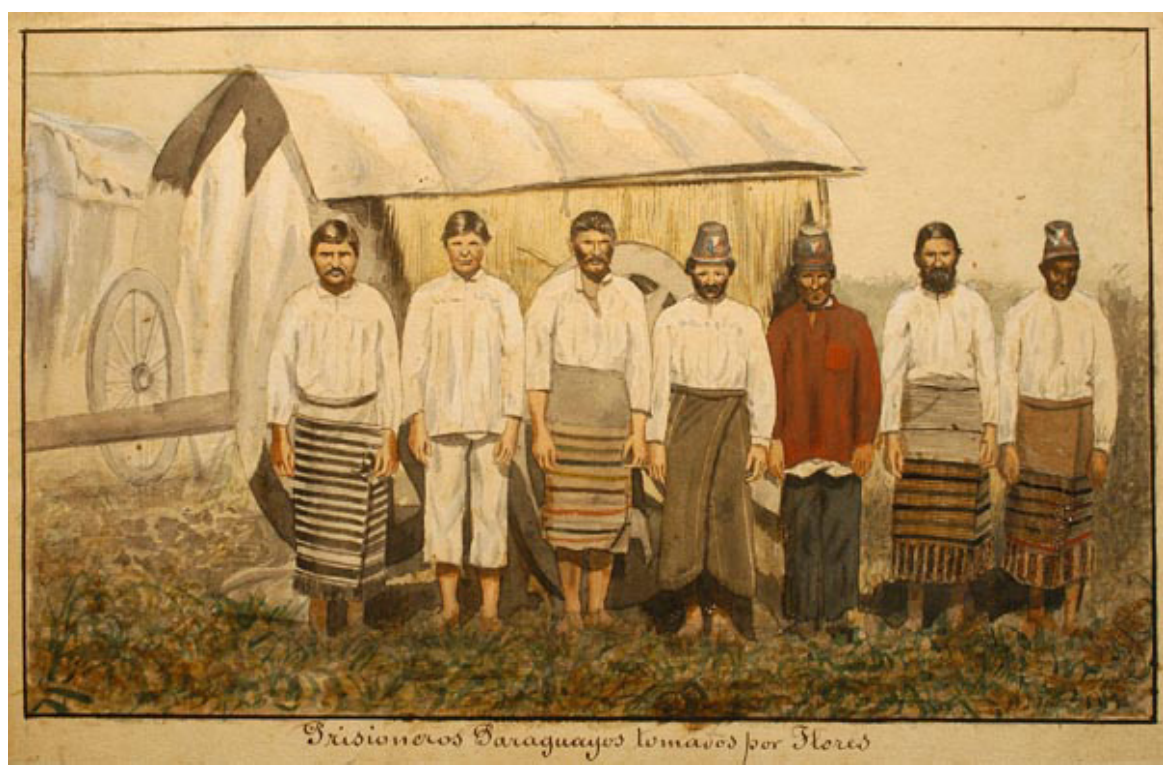

Fig. 24. Adolf Methfessel (1836-1909). Este artista suizo realizó dibujos en el propio teatro de operaciones luego litografiados por Pelvilain. Posteriormente, realizó una colección de acuarelas para el Dr. Estanislao Zeballos como la que apreciamos. 1866. Acuarela. Complejo Museográfico Enrique Udaondo, Luján, Prov. de Buenos Aires. Cortesía Sr. Mario Chaves, Buenos Aires

\section{Mangrullo del Comandante Pipo Giribone en Tuyu-Cué}

Una fotografía que ha sido reiteradamente reproducida en distintas obras que tratan sobre la guerra de la Triple Alianza, es la conocida comúnmente como el mangrullo del Comandante José Pipo Giribone en el campamento aliado de Tuyu-Cué. Giribone. Este genovés, al servicio del ejército argentino y jefe del batallón Legión Voluntarios integrado por mercenarios europeos predominantemente italianos, culminó trágicamente sus días en un combate contra los soldados paraguayos.

Es interesante establecer las distintas representaciones que ha tenido la imagen, tomada por el fotógrafo Carlos César, quien realizó una numerosa serie de tomas fotográficas tras la caída de Humaitá, contando con el aval y el patrocinio del Emperador Pedro II. La misma, más recientemente, también ha sido objeto de confusiones de identidad, atribuida a un puesto de observación brasileño durante la guerra e incluso, utilizada por el general José Ignacio Garmendia, escritor y artista para representar un episodio referido a otro batallón argentino, más precisamente, el Batallón $1^{\circ}$ de Guardias Nacionales de la Ciudad de Buenos Aires, comandado por el propio Garmendia (Cf. Figura 27).

Como alternativas de esta misma fotografía (Fig. $\mathrm{N}^{\circ} 25$ ), nos encontramos con la albúmina que forma parte del álbum "Lembrança do Paraguai" de la Fundación Biblioteca Nacional de Río de Janeiro, con el título siguiente: "O coronel Pipo Giribone e alguns de seu soldados formados diante de um mangrulho" (Salles, 2003: 50); así como la perteneciente al Complejo Museográfico "Enrique Udaondo", Luján, Provincia 
de Buenos Aires, reproducida por el especialista argentino Miguel Ángel Cuarterolo, estableciendo que fue realizada por un fotógrafo no identificado, con el título de "El mangrullo de José Giribone", midiendo la albúmina, 10 X $15 \mathrm{~cm}$. y datando de 1868 (Cuarterolo, 2000: 85).

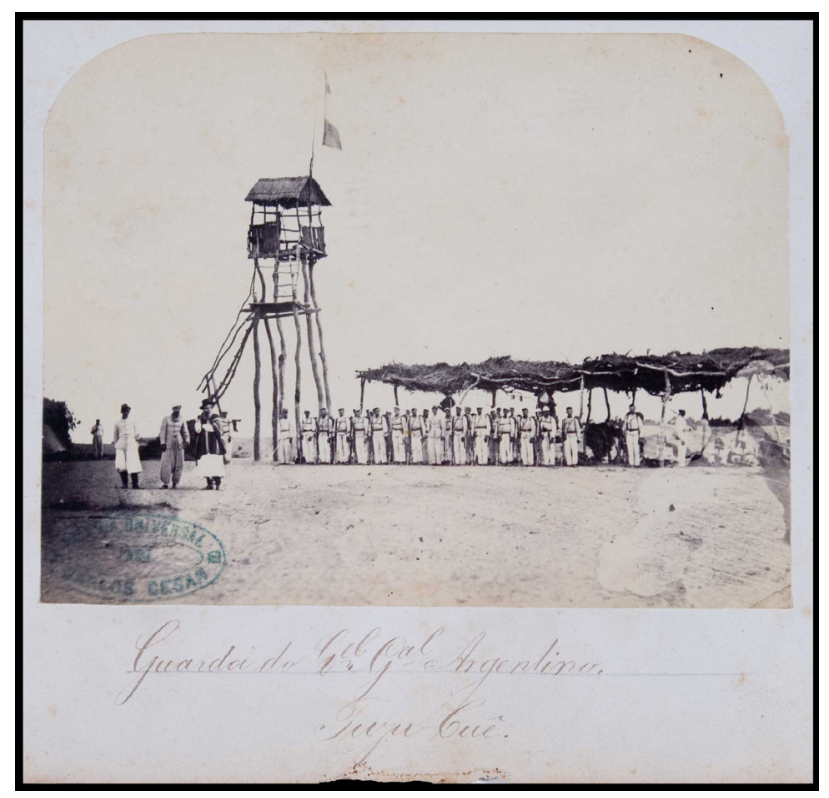

Fig. 25. Carlos César. Galería Universal "Guarda do Q.el G.al Argentino/ Tuyu Cué.”. Esta imagen fotográfica dio origen a varias representaciones y también, lugar a tergiversaciones respecto de su identidad. 1868. Albúmina, formato portrait cabinet. Museo Histórico Nacional, Río de Janeiro.

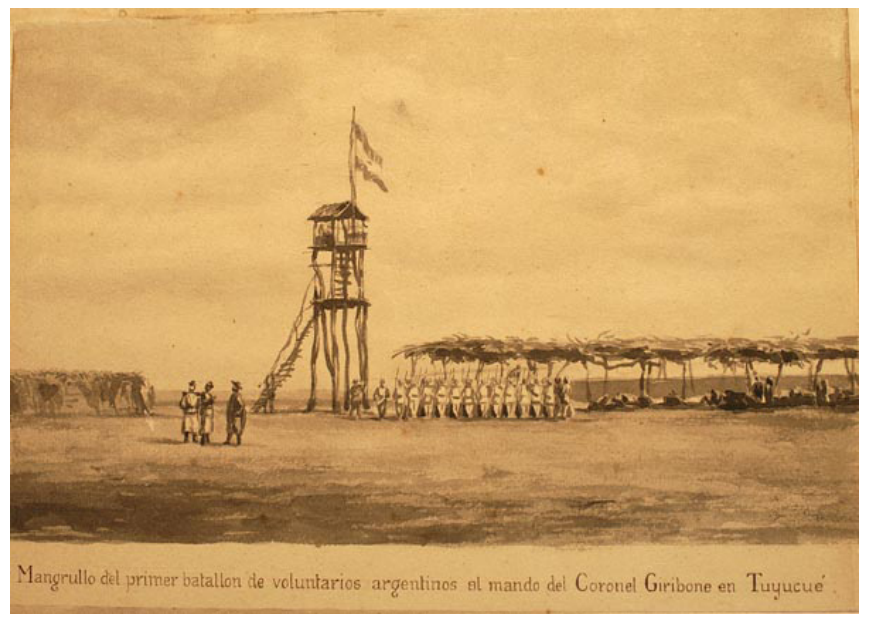

Fig. 26. Adolf Methfessel (1836-1909). "Mangrullo del primer batallon de voluntarios argentinos al mando del Coronel Giribone en Tuyucué”. 1868. Acuarela. Complejo Museográfico Enrique Udaondo, Luján, Prov. de Buenos Aires. Cortesía Sr. Mario Chaves, Buenos Aires 


\section{DOSSIER}

Del Pino. Relaciones entre fotografía y demás iconografía de la Guerra del Paraguay

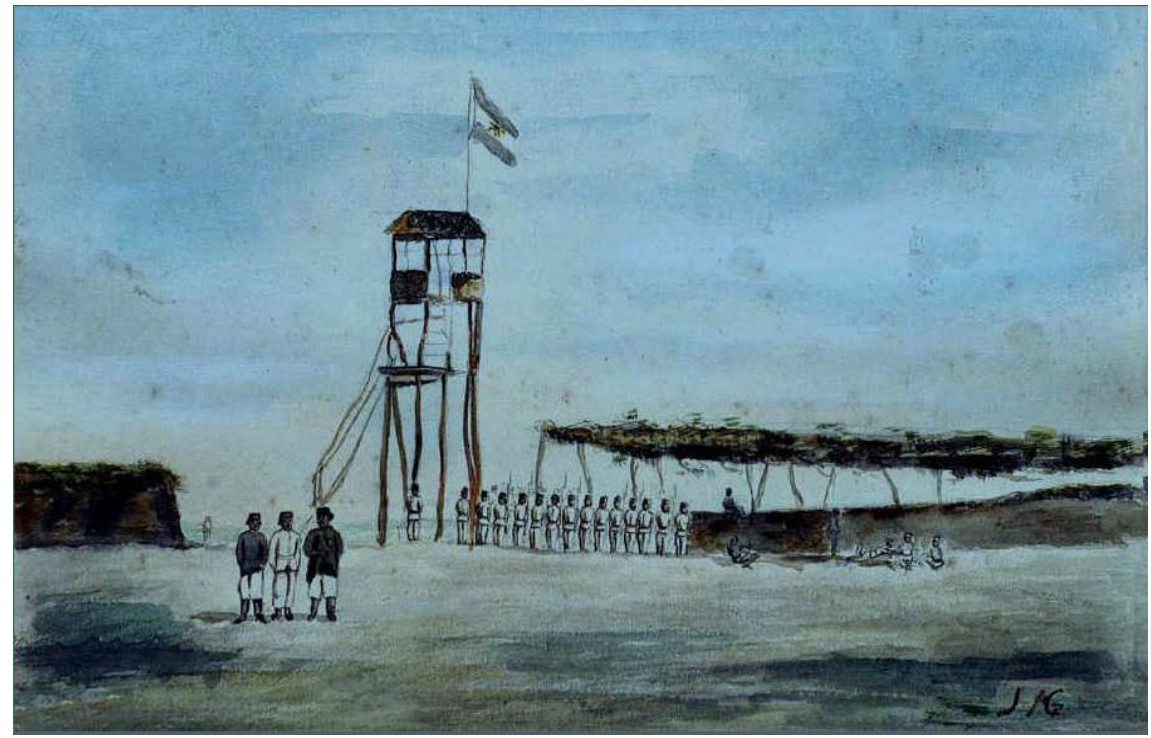

Fig. 27 José Ignacio Garmendia "Mirador del 1er.Batallón de la 1ª División. Buenos Aires en Tuyu-Cué". 1868. Acuarela, 147 X 201mm., Museo de la Ciudad de Buenos Aires "Cornelio Saavedra", Buenos Aires, cortesía Lic. Alberto Piñeiro.

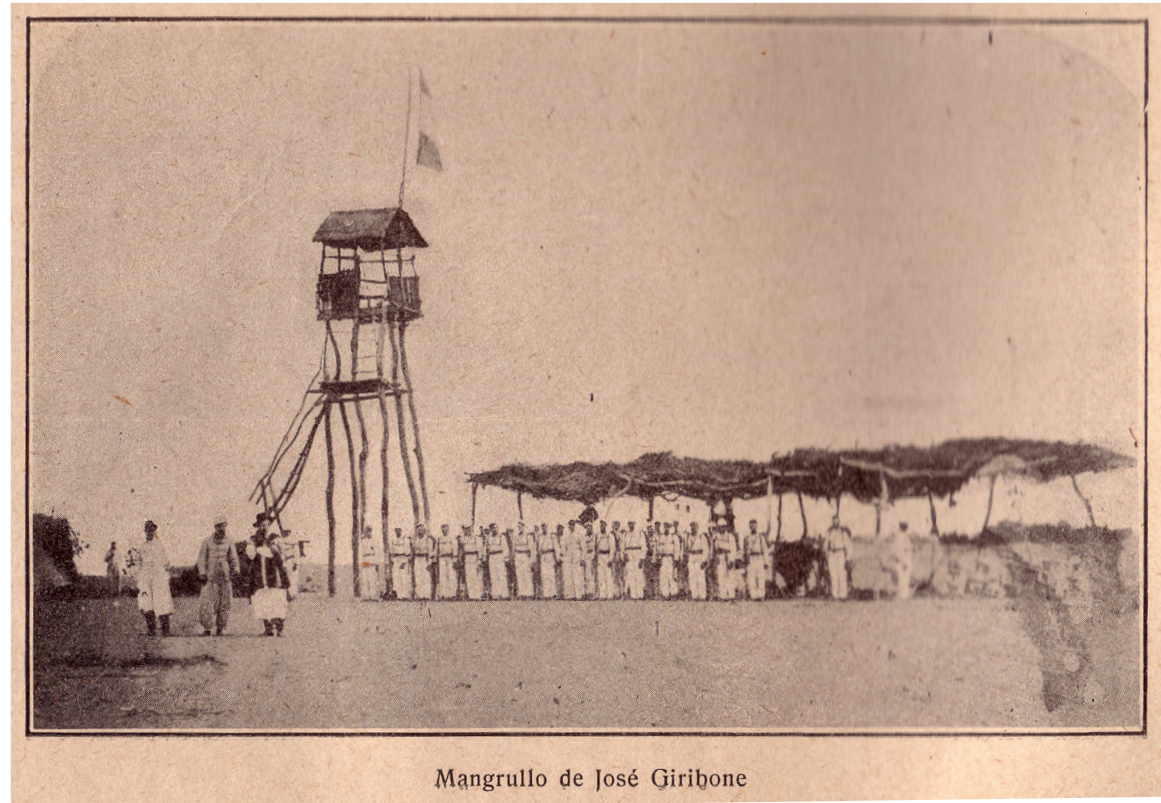

Fig. 28. "Mangrullo de José Giribone". Fotografía reproducida en la obra de George Thompson, "La Guerra

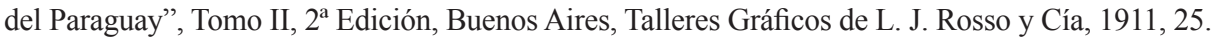

Contemporáneamente, esta misma imagen fue reproducida con la siguiente leyenda: "MANGRULLO Mirador de la época de la guerra", en la obra de Jorge Federico Masterman "Siete años de aventuras en el Paraguay”, Buenos Aires, Palumbo, 1911. 


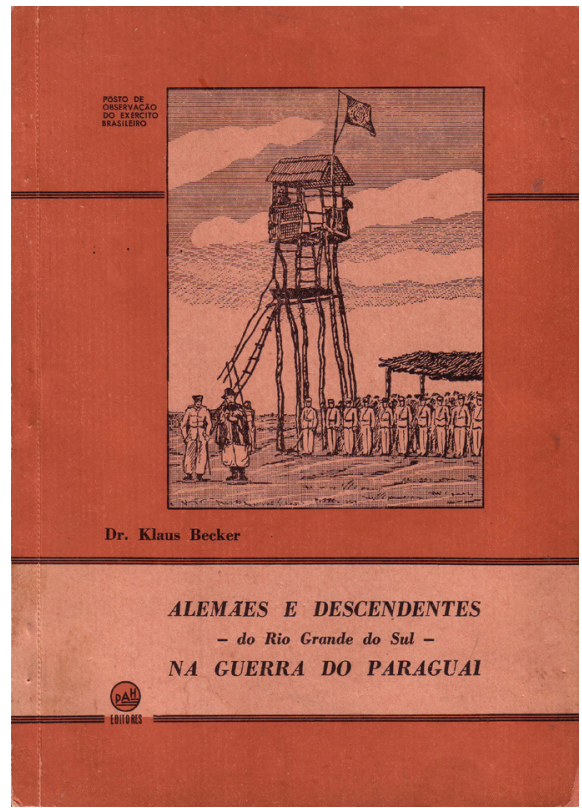

Fig. 29. La fotografía de marras sirvió para el dibujo de la tapa del libro del Dr. Klaus Becker "Alemaes e descendentes - do Rio Grande do Sul- na Guerra do Paraguai", 1968), con la leyenda errónea,

"Posto de observaçao do Exército Brasileiro". Presumiblemente esa confusión de identidad, llevó a otra similar décadas después, ya que la sempiterna fotografía del mangrullo argentino de Giribone, volvió a ostentar erróneamente la leyenda "Posto de observaçao do Exército Brasileiro no Paraguai, s/d", ahora en la obra "Guerra do Paraguai 130 anos depois", 2ª Ediçao, Rio de Janeiro, Relume- Dumará, 1995, Iconografia da Guerra do Paraguai, Coleçao Biblioteca Nacional, R.J., 107)

\section{Las series fotográficas de la Guerra del Paraguay y su dispersión}

Los conjuntos procedentes del reportaje gráfico de carácter serial temático de los fotógrafos durante la guerra, con el paso del tiempo han tendido a dispersarse desde su lugar originario, en repositorios públicos y privados, lo cual ha motivado el sugestivo y feliz título del Dr. André Toral "Imágenes en desorden".

La dispersión obedeció a motivos de diversa índole. La pérdida de los negativos por la acción del clima imperante en el teatro de operaciones o en el caso del cierre de las firmas comerciales donde se reunían los materiales originariamente y el destino incierto de las copias originales, vendidas contemporáneamente; la desaparición física de los propietarios de colecciones particulares, donde se reunían masivamente estos materiales; la venta o donación de esas mismas colecciones a distintos repositorios públicos y privados, que malograron el trabajo original arduo, fatigoso y amoroso de recolección del material.

Elijo en magra selección a cuatro -quizás los mayores especialistas del temaeruditos conocedores de aquel conflicto armado y eximios coleccionistas a la vez: Estanislao Zeballos (Argentina), José María Fernández Saldaña (Uruguay), José Antonio Vázquez (Paraguay), y Mario Barreto (Brasil). A la saga de estos, el brasileño Arthur Montenegro y el argentino, pero uruguayo por adopción y trayectoria, Augusto Schulkin. 
Obviamente que estas situaciones mermaron las posibilidades de conocer de qué manera se custodiaba originalmente el material de procedencia y cuanto se ha perdido y cuanto conservado del núcleo primigenio en los repositorios públicos actuales, donde hoy se encuentran esos fondos documentales, excepto el de Schulkin, subastado en Montevideo y diseminado entre coleccionistas particulares desde el fallecimiento de aquel investigador. En Montevideo, hoy se debe acudir a los acervos iconográficos del Museo Histórico Nacional y la Biblioteca Nacional para lograr reunir la colección completa de las fotografías que componen la serie de Bate \& Cía, "La Guerra contra el Paraguay".

Conocer cuáles son las fotografías que conforman una serie iconográfica se convierte en tarea ineludible para el investigador que elije explorar imágenes representando episodios ocurridos durante la Guerra del Paraguay. Se supone que un fotógrafo realiza diversas tomas sobre un mismo objeto, representándolo desde diversos enfoques, a veces sucesivos. Existen numerosos ejemplos que avalan esta realidad, como lo son la secuencia de los tiradores cearenses en guerrilla, los amontonamientos de cadáveres momificados paraguayos en Potrero Piriz, y la artillería aliada actuando el 18 de julio de 1866, cobertura de Javier López para la firma Bate \& Cía de Montevideo. Asimismo, las espléndidas series tomadas -ya más avanzada la guerra- en Tuyu-Cué, San Solano y Tayí, y sobre todo en Humaitá en ruinas, y que pertenecen a la cámara de Carlos César, fotógrafo comisionado por el Emperador Pedro II.

Veamos lo que dice al respecto Félix del Valle Gastaminza en su trabajo "Dimensión documental de la fotografía", respecto a la relación esencial que existe entre las fotografías componentes de una misma serie:

"Otro atributo relacional importante, especialmente dentro de la fotografía documental, es el que se establece por la pertenencia de la fotografía a una serie o reportaje. Cualquier fotógrafo sabe que casi nunca haces una sola fotografía de algo; más bien lo rodeas, lo exploras y lo representas desde distintos ángulos y con varios enfoques. Luego, quizás, eliges una fotografía y la haces pública. Pero en el archivo queda el resto. Muchas fotografías antiguas, por diferentes razones, están desgajadas de su serie original, y si queremos comprenderlas mejor como portadoras de información es importante conocer el resto de fotografías tomadas (del Valle Gastaminza, 2002).

Un relato del oficial uruguayo Alfredo Parodi, correspondiente al 3 de octubre de 1866, nos permite datar exactamente cuando fue tomada una de las imágenes de la firma Bate y Cía: "Otro día hermoso como el de ayer" -nos dice en el campamento aliado de Tuyutí- "Se han retratado los batallones 24 de Abril é Independencia formados en columna con distancia de mitades" (del Pino Menck, 2008: 152). De estos retratos, solo llega a nosotros, la "novena vista" ( $2^{\mathrm{a}}$ colección, $1^{\mathrm{a}}$ serie, "La Guerra contra el 
Paraguay"), "Batallón Independencia en columna", ignorando la suerte que le cupo a la otra toma realizada.

A continuación presentamos unas fotografías constituidas en gráico ejemplo que nos habla de la referida dispersión:

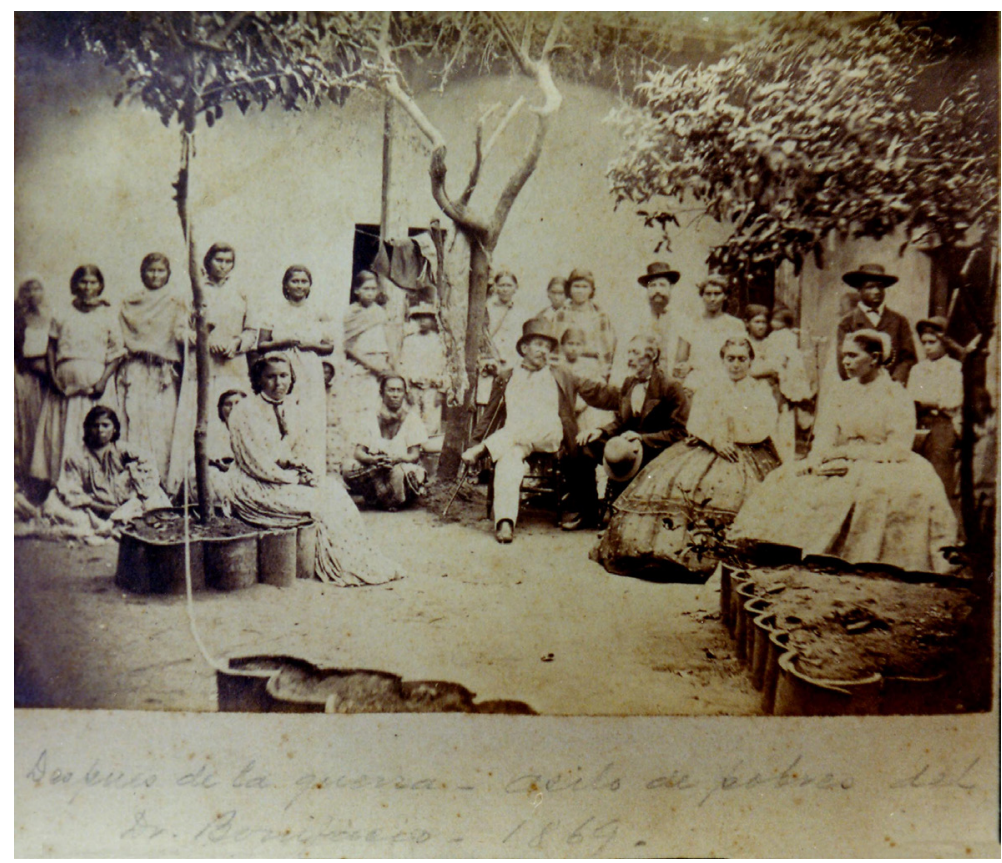

Fig. 30 Anónimo “Despues de la guerra - Asilo de pobres del Dr. Bonifacio - 1869”Albúmina, formato portrait cabinet. Colección José Antonio Vázquez, Museo del Barro, Asunción, cortesía Arq. Osvaldo Salerno.

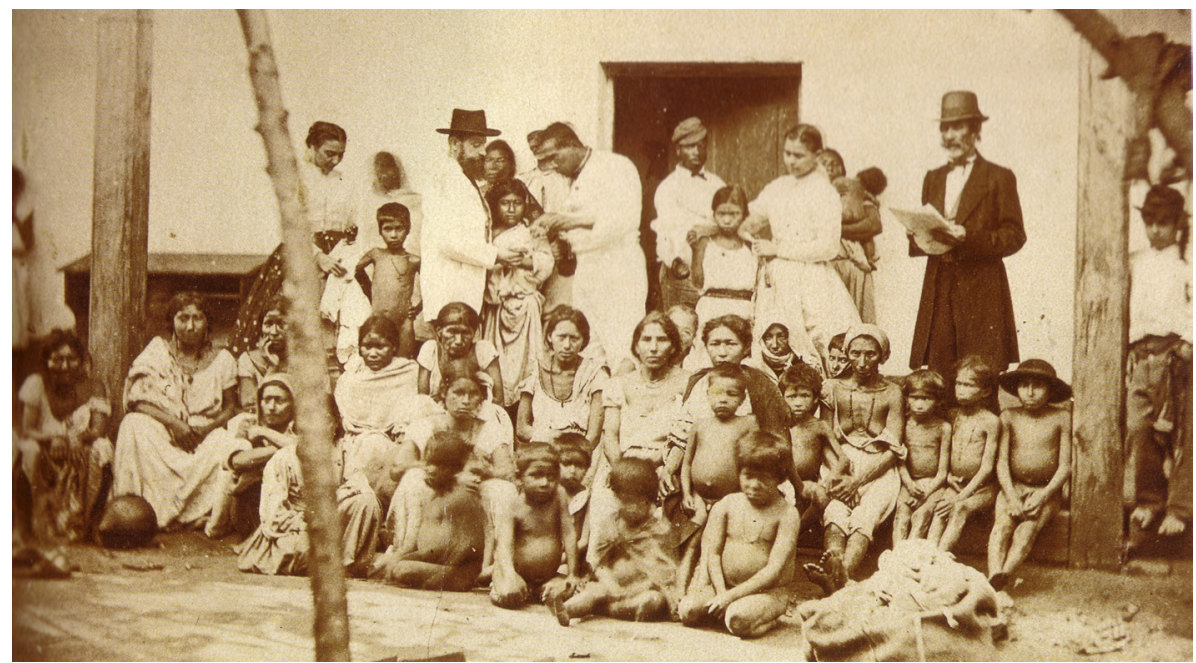

Fig. 31. Fotografía reproducida en el libro de Salles (Guerra do Paraguai, Memórias e Imagens, 165) cuyo original se custodia en el Archivo Nacional, Rio de Janeiro. 


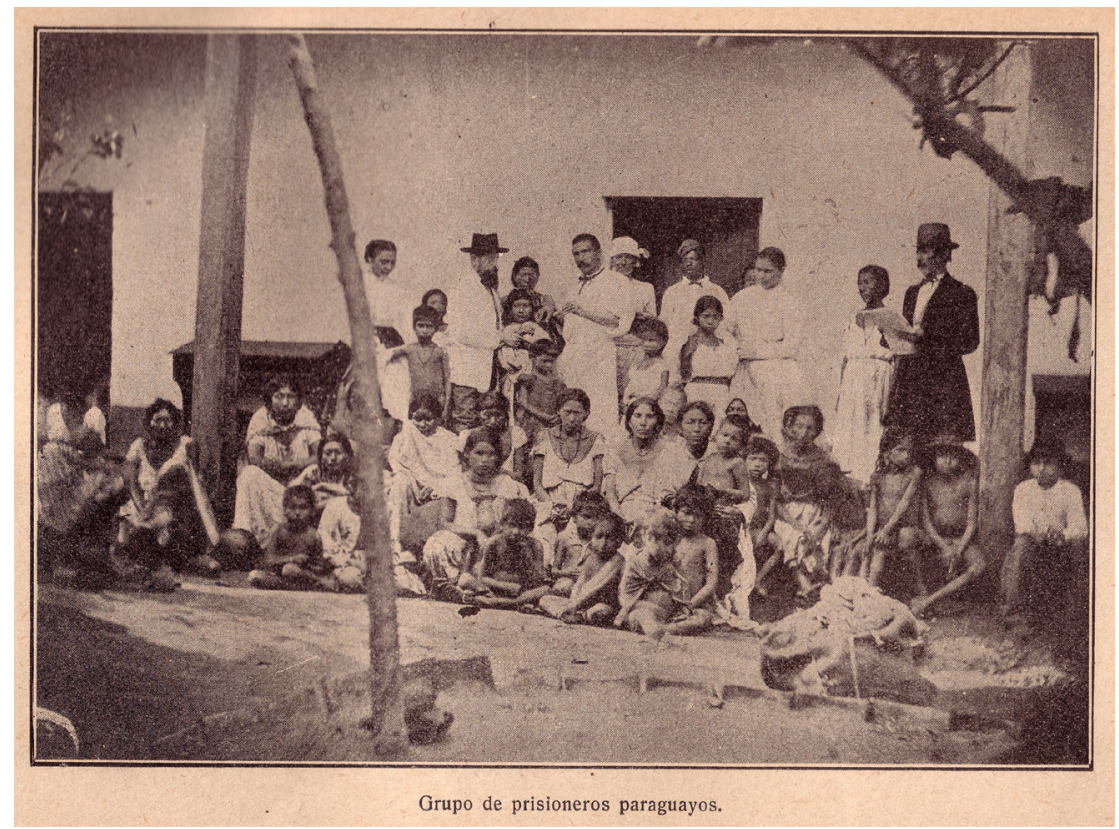

Fig. 32. Anónimo "Grupo de prisioneros paraguayos." Fotografía publicada en la edición en dos tomos de la clásica obra de Thompson, con una corta e inconsistente leyenda. (La Guerra del Paraguay, Tomo Segundo, Buenos Aires, Rosso \& Cía, 1911: 92)

Sigue una relación de los repositorios consultados y que custodian en sus acervos, fotografias originales de la Guerra de la Triple Alianza:

Paraguay: Instituto de Historia Militar y Museo Militar del Ministerio de Defensa Nacional, Asunción; Biblioteca Nacional, Asunción; Museo y Biblioteca de la Fundación Carlos Alberto Pusineri Scala, Puerto Sajonia, Asunción; Centro de Artes Visuales Museo del Barro, Foto documental de la Guerra contra la Triple Alianza de la colección Dr. José Antonio Vázquez, Asunción.

Brasil: Serviço de Documentação Geral da Marinha, Rio de Janeiro; Biblioteca Rio-grandense, Ciudad de Rio Grande; Museu Imperial, Petrópolis, Rio de Janeiro; Biblioteca Nacional, Rio de Janeiro; Museu Histórico Nacional;

Argentina: Complejo Museográfico "Enrique Udaondo", en Luján, Provincia de Buenos Aires; Museo Mitre, Ciudad de Buenos Aires, Sección Fotografía Antigua; Museo Histórico de la Ciudad de Buenos Aires "Brigadier General Cornelio Saavedra", Ciudad de Buenos Aires; Museo Histórico Provincial "Tte. Gdor. Manuel Cabral de Melo y Alpoín", Ciudad de Corrientes, Argentina.

Uruguay: Biblioteca Nacional, Sala de Materiales Especiales, Montevideo, Uruguay; Museo Histórico Nacional, Casa de Giró, Montevideo, Uruguay. 


\section{Conclusión}

Aunque en forma mucho más modesta que en el conflicto armado norteamericano entre norte y sur de 1861-1865, la guerra del Paraguay o de la Triple Alianza, generó un importante cantero iconográfico, contemporáneo o posterior a la misma. Porción sustancial del mismo, lo constituyen las fotografías.
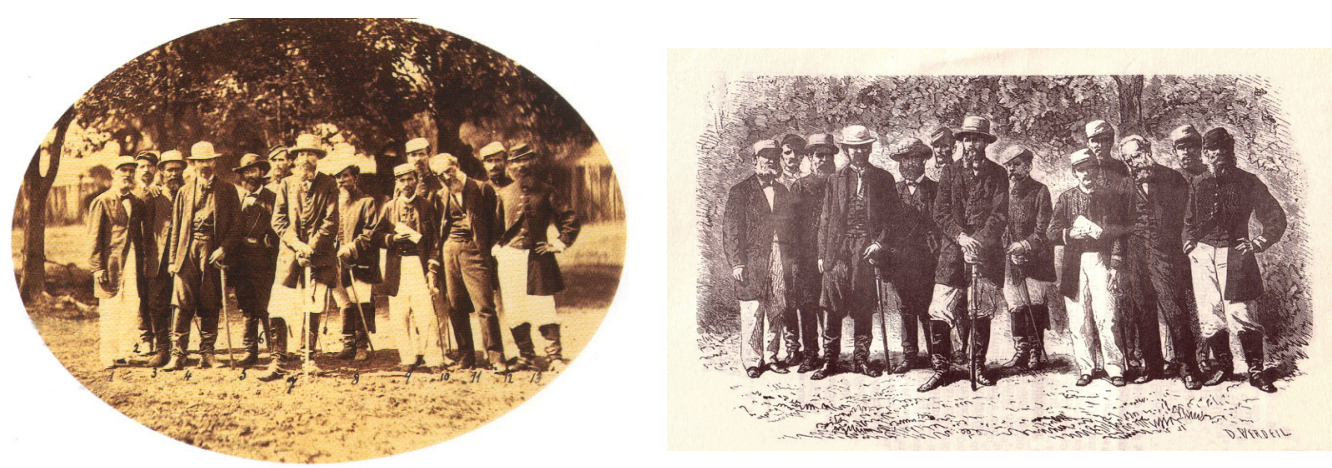

Fig. 33. Anónimo "S.A. Real Conde d'Eu com seu estado maior em Lambaré". Albúmina, formato portrait cabinet. Álbum "Lembrança do Paraguai", Fundaçao Biblioteca Nacional, Rio de Janeiro; Fig. 34. D. Verdeil. El Conde d'Eu con su Estado Mayor. Litografía, 1870, L'Illustration, Paris, edición del 4 de junio de 1870.

Sus autores más expresivos y que afortunadamente, han dejado rastros de su presencia lo cual nos permite magramente identificarlos, han sido Javier López, Carlos César, Antón Cattermole, Carlos Erdmann, Agostino Forni y José Mortola. Si a estos fotógrafos le sumamos la labor de otros anónimos, apostados en estudios fotográficos próximos al teatro de operaciones o incorporado a ellos, ya sea en los campamentos, en las ciudades capitales de los países aliados o en la propia Asunción, tendríamos que sumar a muchos otros más. Los hermanos Bernadet en Corrientes y en Asunción, Luis Terragno en Porto Alegre, Bate y Cía en Montevideo son un ejemplo de esta nómina. Incluso debemos referirnos a improvisados fotógrafos en el campo paraguayo como el inglés Jorge Federico Masterman o el italiano Domingo Parodi, habiendo este último, retratado en las postrimerías de la guerra, al Mariscal López y a otros oficiales destacados de su ejército, entre los que se cuentan, su propio hijo, Francisco López y el Mayor Escobar.

Establecemos algunos de los aspectos que a nuestro juicio han obstado para un adecuado conocimiento del estado actual de las colecciones: dispersión regional de los archivos iconográficos e inadecuada catalogación en repositorios públicos y privados; descuido respecto al principio de procedencia de las colecciones cuando estos ingresan a otro repositorio; pérdida del atributo relacional esencial al dispersarse una serie fotográfica determinada; y por último, el volumen creciente de libros y artículos con contenido iconográfico relacionado con la Guerra del Paraguay dispara confusiones de identidad, así como la necesidad imperiosa de incorporar metodologías no tradicionales 
en el campo de la historia para la identificación de las fotografías, como ser, conocimiento de la vestimenta y mobiliario de la época, así como las características de los estudios fotográficos que operaban durante el conflicto.

Para finalizar, se destacan los abordajes, recientes y pasados sobre la fotografía de la guerra, los cuales valoran a la misma no solo por su valor icónico sino también por su rol como documento histórico propiamente dicho, con todos sus significantes y significados (autor, año en fue tomada, motivo, características, etc.). Todo esto hace imprescindible un acercamiento a nivel regional entre los distintos repositorios públicos y privados. De esta manera, se podrá finalmente conocer y difundir debidamente, la rica e inexplorada iconografía, legado de aquella tragedia del pasado que asolo a cuatro naciones sudamericanas por cinco años.

\section{Referencias bibliográficas}

Cuarterolo, M. A. 2000. Soldados de la memoria. Imágenes y hombres de la Guerra del Paraguay, Buenos Aires, Planeta.

Cuarterolo, M. A. 1995. "Una guerra en el lienzo. La fotografía y su influencia en la iconografía de la guerra del Paraguay". En: Historia de la Fotografía, Memoria del $4^{\circ}$ Congreso de Historia de la Fotografía en la Argentina, Buenos Aires.

De Palleja, L. 1960. Diario de la Campaña de las Fuerzas Aliadas contra el Paraguay, Colección de Clásicos Uruguayos, Montevideo, Ministerio de Instrucción Pública y Previsión Social, tomo I, volumen 29.

De Marco, M. A. 1995. La Guerra del Paraguay, Buenos Aires, Grupo Editorial Planeta.

De Marco, M. A., Cavanagh, C., Garmendia, J. I. 2005 Crónica en imágenes de la Guerra del Paraguay, Pontificia Universidad Católica Argentina, Pabellón de las Bellas Artes, Facultad de Filosofía y Letras, Buenos Aires, República Argentina, Imprenta Brapack S.A.

Del Pino Menck, A. 1997. "Javier López, fotógrafo de Bate \& Cía en la Guerra del Paraguay”. En: Boletín Histórico del Ejército, Año 68, № 294-97, Montevideo, Uruguay. pp. 33-69.

Del Pino Menck, A. 2009. Imágenes de la Guerra del Paraguay y confusiones de identidad. En: Anais do Colóquio Ibero-Sul-Americano de História -entre os dois lados do Atlántico, Instituto Histórico e Geográfico de Florianópolis, Santa Catarina, Brasil. 317-374.

Del Pino Menck, A.; Fernández Labeque; A.; Villa, J. y Gargiulo, G. 2008. La Guerra del Paraguay en fotografias, Biblioteca Nacional, Montevideo.

Del Valle Gastaminza, F. 2002. Dimensión documental de la fotografía, Universidad Complutense de Madrid. Conferencia Magistral leída el 29 de Octubre de 2002 en el Congreso Internacional sobre Imágenes e Investigación Social celebrado en México D.F. del 28 al 31 de Octubre de 2002 y organizado por el Instituto de Investigaciones Dr. José María Luis Mora, URL: http://www.montevideo.gub. 
uy/sites/default/files/concurso/materiales/anexo_3.1_-_del_valle.pdf, consultado el 30 de abril de 2015

De Marco, M. A. y Cavanagh, C. 2005. José Ignacio Garmendia. Crónica en imágenes de la Guerra del Paraguay, Pontificia Universidad Católica Argentina, Pabellón de las Bellas Artes, Facultad de Filosofía y Letras, Buenos Aires, República Argentina.

Escobar, T.; Salerno, O. y Seiferheld, A. M. 1985. La guerra del 70; una visión fotográfica. Edición Museo del Barro, Asunción, Paraguay.

Ferdinán, V. 1989. Relaciones entre fotografía y pintura en el Montevideo del siglo XIX, Universidad de la República, Facultad de Humanidades y Ciencias, Montevideo.

Fernández Labeque, A.; Gadea Sellanes, G.; Mendive, G.; Villa, O. J. 1979. "Investigación de una serie fotográfica de la Guerra del Paraguay a través de la imagen" En: La fotografía en la perspectiva histórica nacional, Revista de la Biblioteca Nacional, No 19, Montevideo, pp. 133-147.

Fernández Saldaña, J. M. 1927. "Las fotografías de la guerra del Paraguay". En: Suplemento Semanal del Diario La Mañana No 231, Febrero 6 de 1927, Montevideo.

Fernández Saldaña, J. M. 1943. "La guerra hace 3 cuartos de siglo. Notas gráficas de la Campaña del Paraguay”, En: Suplemento Dominical del Diario El Día, octubre 31 de 1943, Montevideo.

Fonseca de Castro, A. H. 2005. "O retrato de meu pai. Preservação da memória do Exército pelas fotografias pessoais", En: Revista Da Cultura, Ano V, No 9, Dezembro, pp. 7-14.

Fonseca de Castro, Adler Homero. 2006. "Dois retratos, uma guerra”. Em: História Viva, Vol. 36, São Paulo, pp. 80-83.

Giordano, M. y Amigo, R. 2008. La épica y lo cotidiano. Imágenes de la Guerra Guasú. 1865-1870, Museo Provincial de Bellas Artes "Dr. Juan Ramón Vidal".

James, Lawrence. 1981. 1854-56. Crimea. The war with Russia from contemporary photographs, New York, Van Nostrand Reinhold Company.

Kossoy, Boris. 2002. Diccionario Fotográfico Brasileiro. Fotógrafos e oficio da fotografa no Brasil (1833-1910), São Paulo.

Piñeiro, A. G.; Rubio, A. y Sánchez, M. A. 2006. El horror de la guerra. Personalidades y escenas de la guerra de la Triple Alianza contra el Paraguay por José Ignacio Garmendia y J. Serena, Buenos Aires, Museo Histórico de la Ciudad de Buenos Aires "Cornelio Saavedra".

Riego, B. 1996. "El documento fotográfico y sus significaciones temporales". En: Memorias del $5^{\circ}$ Encuentro de Historia de la Fotografía en la Argentina, Buenos Aires, pp. 163-173.

Salles, Ricardo. 2003. Guerra do Paraguai. Memórias \& Imagens, Rio de Janeiro, Edições Biblioteca Nacional.

Sanweiss, M. A.; Stewart, R. y Husmean, B. W. 1989. Eyewitness to War. Prints and Daguerreotypes of the Mexican War, 1846-1848, Amon Carter Museum, Fort Worth, Texas. 
Sontag, S. 2003. Ante el dolor de los demás, Buenos Aires, Alfaguara.

Toral, A. A. 2001. Imagens em desordem. A iconografia da Guerra do Paraguai (18641870), Universidade de São Paulo, Brasil.

Toral, A. A. 1999. "Entre retratos e cadáveres: a fotografia na Guerra do Paraguai". En: Revista Brasileira de Historia, Vol. 19, No 38, São Paulo.

Varese, J. A. 2007. Historia de la fotografía en el Uruguay Fotógrafos de Montevideo, Montevideo, Ediciones de la Banda Oriental.

Varese, Juan Antonio. 2013. Los comienzos de la fotografía en Uruguay. El daguerrotipo y su tiempo, Montevideo, Ediciones de la Banda Oriental.

Yubi, Javier. 2012. La Guerra Grande. Imágenes de una epopeya. $2^{\text {a }}$ Edición, Asunción, Paraguay, Editorial Servilibro. 